ISSN: 1305-578X

Journal of Language and Linguistic Studies, 15(2), 649-677; 2019

\title{
A research on reading comprehension and morphological awareness levels of middle school students and the relationship between these concepts
}

\author{
Muhammet Raşit Memiş a * \\ ${ }^{a}$ Ondokuz Mayls University, Atakum, Samsun, 55200, Turkey.
}

\section{APA Citation:}

Memiş, M. R. (2019). A research on reading comprehension and morphological awareness levels of middle school students and the relationship between these concepts. Journal of Language and Linguistic Studies, 15(2), 649-677.

Submission Date: 27/03/2019

Acceptance Date: 07/06/2019

\begin{abstract}
This study aims to determine the levels of reading comprehension and morphological awareness in middle school students and to examine the dimensions of these two concepts by illustrating the existence of a relationship between them. The study group of the research conducted with the relational screening model consists of 1561 students in the $5^{\text {th }}, 6^{\text {th }}, 7^{\text {th }}$ and $8^{\text {th }}$ grades from the cities located in six different regions of Turkey. Morphological awareness test and the reading comprehension tests developed separately for each grade were used in the collection of data obtained between the years of 2016-2018. According to the results, it was seen that the reading comprehension levels of the middle school students were moderate, that there was a significant difference between the grades in terms of the success in the reading comprehension in favor of the upper grades, and that the female students had better reading comprehension skills compared to the male students. According to the other results obtained from the research, it was observed that the students in the $5^{\text {th }}$ and $6^{\text {th }}$ grades were at a low level in terms of morphological awareness, that the levels of the students in the $7^{\text {th }}$ and $8^{\text {th }}$ grades were moderate, and that there was a significant difference among the grades and between the genders in terms of the success. Lastly, it was understood that there was a high-level relationship between the reading comprehension and morphological awareness. Accordingly, it was determined that the success in morphological awareness was at a higher level in the students having a high rate of success in terms of reading comprehension, and that the students having lower morphological awareness got lower scores in reading comprehension tests.
\end{abstract}

(C) 2019 JLLS and the Authors - Published by JLLS.

Keywords: Reading comprehension; morphological awareness; native language education; middle school grade

\section{Introduction}

The main objective of the native language education is to ensure that the individuals can effectively use their mother tongues in all linguistic forms. Accordingly, the training process is focused on the balanced development of the linguistic skills. The features of sound, form, meaning, and syntax of the native language are offered as a part of the educational activities according to the level of the students in the development process of the linguistic skills. Knowing these characteristics of the language

\footnotetext{
* Corresponding author. Tel.: +90-362-312-1919/5487
}

E-mail address: muhammet.memis@omu.edu.tr 
increases the awareness of the students on their mother tongue, and it positively affects the development of the linguistic skills. For instance, a student who does not know the rule of consonance in Turkish will never improve his/her writing abilities in its fullest sense. This student will inevitably make spelling mistakes in written expressions. A student who is not aware of the morphological characteristics of the Turkish language will be deprived of the information which is fundamentally based on the suffixes and that directly affects the meaning, and this deficiency will incapacitate the student from giving meanings to the words especially in the reading process and from producing new words or changing their forms in expressive situations. These reasons point out the fact that the features of a language should be taken into consideration in the development process of the linguistic skills and that awareness must be created in this regard. In this study, it was aimed to examine the relationship between the reading comprehension, which is one of the main linguistic skills, and the concept of morphological awareness that includes the structural features of a language. For this reason, a comprehensive literature review was considered to be necessary for the above-mentioned two concepts.

\subsection{Reading Comprehension}

Reading, which is one of the four basic language skills, is defined in the literature as "the process of evaluating and interpreting the signs and symbols perceived through the speech organs and eyes in the brain" (MEB, 2006, p.6), "a complicated emotional and mental activity consisting of different components such as seeing, attention, focusing, perception, remembering, interpretation, synthesizing, analysis, explication, and vocalization" (Karatay, 2010, p. 459), and "an effective and fluent process comprising the interaction between the reader and the reading material in order to get the meaning" (Anderson, 1999, p. 1). "This process requires the mutual operation and usage of numerous different processes such as attention, focusing, perception, comprehension, interpretation and remembering, and the cognitive functions related to these mechanisms" (Block and Pressley, 2002; Grabe and Stoller, 2002). The main purpose of reading is to get the meaning. Reading without focusing on the meaning is just a mechanical vocalization. Meaning enables the reading process to go beyond the borders of a mechanical action and to turn into a mental activity.

Comprehension is defined as "the ability to understand the information obtained through listening or reading by means of various mental operation processes" (Gögüş, 1978) and "a way of thinking, exploring, extracting and evaluating the causes and results of the information received through listening, reading and visual reading" (Güneş, 2007, p. 229). The main objective of the reading process is not to decipher the codes of the words or phrases expressed through written symbols, but to comprehend them. "Reading is a creative activity based on comprehension, and comprehension is not a consequence of the reading but the basis of it" (Smith, 1988). Reading and comprehension, which are thought to be two different concepts and two different processes, are essentially complementary and connected to each other with a cause-effect relationship.

The terms "reading" and "comprehension" come together to form the concept of reading comprehension. The reading comprehension is defined as "perceiving, understanding and comprehending written texts and grasping the information, emotions, and thoughts with all possible dimensions within their own flows and without causing any mistake or doubt" (Kavcar and Oğuzkan, 1987, p. 43), "understanding the thoughts and messages intentionally written by the writer" (May and Rizzardi, 2002), "interacting with the text constructing the meaning through the integration of the reader's prior knowledge and experience with the relationships and content of the text, in other words, constructing the meaning" (Pardo, 2004 , p. 272), "interpreting and forming the meaning in a text simultaneously through the interaction and usage of the written language" (Snow, 2002, p. 11), "constructing the meaning in the written text by means of the mutual exchange between the reader and 
the message to be given in the text" (Harris and Hodges, 1995), and "obtaining and forming the meaning in the text simultaneously with the written interaction and interchange" (RSG, 2002). The reading comprehension indicates the ability to obtain information from a written text, to understand the information or to use it in the situations where the efficiency of the information can be demonstrated (Brassell and Rasinski, 2008, p. 17). The reading comprehension process includes certain efficient components such as recognizing the words, using preliminary information, understanding the type of the text, motivating, fluent reading, making predictions and getting the important ideas (Tompkins, 2006, p. 223). Reading comprehension is of vital importance for all learning processes.

It is unthinkable for a person to read without having a purpose of comprehending the content under normal conditions. For this reason, comprehension is the real motive of the reading activity, and this action requires a certain process. The reading comprehension activity includes numerous cognitive processes such as recognizing and knowing the meaning of words, focusing, detailing, remembering, deducing and interpreting, thinking, and combining the previous experiences with the new knowledge (Memiş and Kara, 2018, p. 267). Reading instruction, which aims to develop the skills necessary for being successful in the process of understanding the text, is carried out in three stages, namely prereading, while reading and post-reading. The individual carrying out the reading activity should be active in the processes of pre-reading, while reading and post-reading, and s/he should use the strategies required in these stages if necessary so that the reading process can be effectively and successfully completed (Epçaçan, 2009, p. 212). "For the complete realization of the reading comprehension process, the reader should possess the skills of remembering the meanings of the words, deducing the meanings of the words that s/he does not know by using the context, finding the answers to the questions posed explicitly in the text and expressing them differently, connecting the ideas in the content, making deductions from the general context of the text, realizing the purpose, message and technique of the author, finding the main idea and distinguishing the type and structure of the text" (Davis, 1968 cited in Anderson, 2000, p. 9-10). "The individual who possesses these skills can learn new words from the texts s/he reads, s/he can; give the most appropriate meaning to the unknown words based on the clues and general context, identify the type of the text, find out the details in the text and determine the main idea, understand the views, purpose and objectives of the author, give answers to the questions related to the text or asked in the manuscript, summarize the content in his/her own words, and reach various outcomes after reading" (Çiftçi, 2007, p. 70). It can be stated that the person who has the above-mentioned skills is an effective reader. The individuals who effectively read the texts can also focus on the meaning by quickly recognizing the words during the reading process, they set an intent of reading before starting to read the text, they are in need of reading, they can realize the words that they misunderstand and correct them, and they can read the text critically by filtering the information given in the text. Effective readers also have a wide range of vocabulary and use various reading strategies while they are reading (Grabe, 1991).

When the studies in the literature are analyzed (Anılan, 2004; Ateş, 2008; Balc1, 2009; Çam, 2006; Çiftçi, 2007; Gelbal, 2008; İşcan, 2009; Karabay ve Kayıran, 2010; Karakuş Tayşi, 2007; Keleş, 2005; Kurnaz, 2018; Özder, vd. 2012; Sallabaş, 2008; Sanır, 2017; Saracaloğlu, vd., 2011; Sidekli, 2005; Yıldırım, vd., 2010; Y1ldı, 2010), it is seen that there are numerous physiological, psychological, demographic and sociological factors affecting the reading comprehension process such as gender, intelligence, socioeconomic level, educational background of the family, reading habit, anxiety, attitude, language development and maturation, vocabulary, social environment, and interests and needs. In addition to the above-mentioned variables, the reading comprehension process is also influenced by the structural and systematic features of the relevant language such as phonology, morphology, syntax, and semantics (Memiş, 2018). At this point, it is necessary to reveal the influence 
of the language on the reading comprehension process and their relationship as well as the impact of the physiological, psychological, demographic and sociological factors on the reading comprehension and the relationship between these factors and the aforesaid process. The studies to be carried out for this purpose will contribute both to a better understanding of the reading comprehension process and to the implementations to be made for the development of the reading comprehension skill.

\subsection{Morphological Awareness}

Morphological awareness, which can also be named as stylistic or formal awareness, consists of knowing the main parts of the words that form the basic units of a language, being aware of these parts and benefiting from this knowledge and awareness when necessary. Morphological awareness is defined in the literature as "the conscious awareness on the structures of the words and the ability to manipulate and reflect these structures" (Carlisle, 1995, p. 194), "a concept related to the learners' comprehension of the structure of words as a combination of meaningful units" (Kieffer and Lesaux, 2008, p. 784), "the ability to skillfully manipulate morphemes, to apply the rules of word formation, and to know and use the rules of word derivation and the prefixes/suffixes in a language" (Kuo and Anderson, 2006, p. 161) and "the awareness on the computational analysis of words" (Leong, 1991; Mattingly, 1987). In other words, it is the ability to recognize the inner structure of a word and to use the rules of word derivation for the formation of a new word by recognizing the roots and prefixes/suffixes. An individual possessing the morphological awareness can break the structurally complex words down into its constituent parts such as root, derivational suffix, and inflectional suffix, and s/he can notice the morphological relationships between the words especially in the process of reading.

Morphological awareness includes the recognition of the morphological structures and of the morphologically complex multimorphemic words (roots, suffixes and combinations), the awareness on the linguistic functions of multimorphemic words, knowledge of the grammatical rules of the target language, consciousness on the linguistic functions of derived words and on the possible differences in the meanings of the new derived words formed with the same suffixes assuming different functions. When these issues are acknowledged, it becomes possible to derive structurally complex multimonomorphemic words from the well-known monomorphemic words and to understand the meanings and usage of these words by means of the internal structures.

Morphological knowledge or awareness begins to develop in pre-school ages of children (Berko, 1958). As time progresses, children become aware of this knowledge, and they begin to analyze certain morphological structures of the words (Carlisle, 2003). They can understand that the names of the objects they encounter in their immediate vicinity are composed of two parts. For example, they realize that the function of the suffix "lik" in the words such as "tuz-tuzluk" (salt- salt shaker), "ayakkabı-ayakkabılık" (shoe - shoe cupboard), "göz-gözlük" (eye- eyeglasses), and they understand that the words containing this suffix consist of two meaningful units. After this realization, they start to produce meaningful words by using the same suffix.

The morphological awareness does not only develop as a result of natural development and maturation of children, or exposure to spoken language. When the resources in the literature are reviewed, it is identified that there are three types of morphological knowledge which play a role in the development of morphological awareness in children. These types are entitled as inflectional morphology, derivational morphology and compound morphology (Berko, 1958; Carlisle, 2000; Ku and Anderson, 2006). 


\subsection{Reading Comprehension and Morphological Awareness}

Although languages have similar characteristics in terms of operating system under certain categories, each language has an idiosyncratic morphological structure. The mentioned structures, appear in all texts produced in the target language, and play facilitative role in reading for those who receive necessary training, and play complicating role for those who don't have the necessary education, in the process of reading comprehension. In the researches which focus on the relationship between reading comprehension and morphological awareness, it is revealed that there is high correlation between morphological knowledge of the students and their success in reading comprehension in 3, 4, 5, 6, 7, 8 and $9^{\text {th }}$ grades students whose native language is English (Foorman, Petscher and Bishop, 2012), that the students whose native language is Spanish, having better performances in terms of morphological awareness also get better scores in reading comprehension (Guimaraes et al., 2014), that the bilingual students whose native languages are Chinese and Spanish, can transfer their morphological awareness in Chinese and Spanish to their second language, which is English (Gomez, 2009). In another research, it has been determined that there is a significant relationship between the structural awareness and the definition of morphologically complicated words and that the morphological awareness makes contribution to reading comprehension skills both in the 3rd and 5th grade students although this contribution is more evident among the 5th graders. In addition to these results, it is also observed that as a result of word formation training, the students with higher reading comprehension skills have shown better performance than the students with lower reading comprehension skills from the knowledge of derivational morphology (Loudermill, 2014).

\subsection{The Problem and the Purpose of the Study}

The studies carried out for illustrating the impacts of morphological awareness on the reading comprehension in language education have revealed that morphological awareness has a positive effect on the success of the individuals in reading comprehension both in their mother tongue and a foreign language, and that this awareness contributes to the process of reading comprehension and interpretation (Carlisle, 2000; Curinga, 2014; Deacon and Kirby, 2004; Fergusson, 2006; Gomez, 2009; Good, 2011; Katz, 2004; Loudermill, 2014; McCutchen et al., 2008; Nagy et al., 2003; Nagy et al., 2006; Pacheco, 2005; Smith, 1998; Tighe, 2015). The majority of these studies were conducted with the participation of the subjects using English as their native language, a second language or a foreign language, and it has been found out that morphological awareness is related to the success in reading. When the studies in the literature have been examined, it has been seen that there is no study investigating the relationship between reading comprehension and morphological awareness in Turkish which is more prone to the morphology. This deficiency also constitutes the research question of this study.

Consequently, with reference to the above-mentioned literature reviews and the aforesaid reasons, the present study aims to determine the level of reading comprehension and morphological awareness in the middle school students and to examine the dimensions of the relationship between these two concepts. Accordingly, the following research questions have been answered:

1. What are the levels of reading comprehension in the $5^{\text {th }}, 6^{\text {th }}, 7^{\text {th }}$ and $8^{\text {th }}$ grade students?

1.1. Do the levels of reading comprehension in middle school students differ according to their grades?

1.2. Do the levels of reading comprehension in middle school students differ according to gender? 
2. What are the levels of morphological awareness in the $5^{\text {th }}, 6^{\text {th }}, 7^{\text {th }}$ and $8^{\text {th }}$ grade students?

2.1. Do the levels of morphological awareness in middle school students differ according to their grades?

2.2. Do the levels of morphological awareness in middle school students differ according to gender?

3. Is there a significant relationship between the levels of reading comprehension and the levels of morphological awareness in the $5^{\text {th }}, 6^{\text {th }}, 7^{\text {th }}$ and $8^{\text {th }}$ grade students?

\section{Method}

\subsection{Research Model}

This research was conducted by means of the relational screening model, which allows the analyses in the type of comparison and correlation, in order to determine the levels of reading comprehension and morphological awareness in the middle school students and the relationship between these two concepts. In the relational screening model, it is aimed to find out the existence and/or the level of the interchange between two or more variables (Creswell, 2012) and to describe a past or present situation the way it is (Karasar, 2016).

\subsection{Population and Sampling}

The population of this research consists of the students studying at middle schools. According to the Ministry of National Education statistics in the 2016-2017 academic year, 5,554,415 students receive education at public, private and distant middle schools in Turkey. Of these students, 2,827,822 are males while 2,726,593 are females. The number of the students studying at public schools is given as follows according to their grades (MEB, 2017, p. 65-99).

Table 1. Numbers of Students in 2016-2017 Academic Year

\begin{tabular}{cccc}
\hline Grades & Male & Female & Total \\
\hline $\mathbf{5}^{\text {th }}$ Grade & 876.614 & 845.854 & 1.722 .468 \\
$\mathbf{6}^{\text {th }}$ Grade & 634.058 & 600.301 & 1.234 .359 \\
$\boldsymbol{7}^{\text {th }}$ Grade & 616.811 & 580.678 & 1.197 .489 \\
$\mathbf{8}^{\text {th }}$ Grade & 610.010 & 569.793 & 1.179 .803 \\
All Grades & 2.737 .493 & 2.596 .626 & 5.334 .119 \\
\hline
\end{tabular}

The error margins are recommended to be in $95 \%$ of certainty level for the cases in which the total number of the population is known $(\alpha=0.05)$, and 348 for the population numbered 1.000 .000 or more (Baş, 2005, p. 47; Cohen et al. 2000 cited in Erkuş, 2005, p. 91). When the number of the middle school students constituting the population of our research was taken into account, it was considered appropriate to include 384 and more students from each grade as subjects. Accordingly, the sampling of the study consisted of 1561 students in total from six cities, namely Samsun, Uşak, Ankara, İstanbul, Muş and Gaziantep that are located in six different regions of Turkey. It is considered that the selection of the schools in different geographical regions as samples will increase the generalizability of the results. The data for the students included in the study are given as follows: 
Table 2. The Numbers of the Students Selected for the Sampling

\begin{tabular}{cccc}
\hline Grades & Male & Female & Total \\
\hline $\mathbf{5}^{\text {th }}$ Grade & $203(\% 51,27)$ & $193(\% 48,73)$ & 396 \\
$\mathbf{6}^{\text {th }}$ Grade & $194(\% 49,49)$ & $198(\% 50,51)$ & 392 \\
$7^{\text {th }}$ Grade & $187(\% 48,19)$ & $201(\% 51,81)$ & 388 \\
$\mathbf{8}^{\text {th }}$ Grade & $199(\% 51,69)$ & $186(\% 48,31)$ & 385 \\
All Grades & $783(\% 50,16)$ & $778(\% 49,84)$ & 1561 \\
\hline
\end{tabular}

As shown in Table 2, the distributions of the students included in the sampling consisting of 1561 persons are listed as follows: 396 students in total for the $5^{\text {th }}$ grade (203 male, 193 female students), 392 students in total for the $6^{\text {th }}$ grade (194 male, 198 female students), 388 students in total for the $7^{\text {th }}$ grade (187 male, 201 female students) and 385 students in total for the $8^{\text {th }}$ grade (199 male, 186 female students).

\subsection{Data Collection Tools}

\subsubsection{Morphological Awareness Test}

A morphological awareness test (MA) was developed by the researcher so that it can be used in determining the morphological awareness of the students. Education program for the Turkish language was firstly examined in the stage of preparation of the morphological awareness test, and it has been found out that the students are beginning to learn morphological knowledge starting from the $5^{\text {th }}$ grade. According to the teaching programs for Turkish language, it is envisaged that the students learn the tasks and functions of the derivational and inflectional suffixes and the meanings given by these suffixes as of the $5^{\text {th }}$ grade. The relevant achievements in the teaching programs for Turkish language in 2015 and 2018 are summarized as follows: "Students can use the inflectional suffixes (case suffixes, possessive suffixes, plural suffixes, genitive suffixes) and derivational suffixes correctly, and they can interrelate the suffixes with root information". (MEB, 2015) "They can distinguish the roots and suffixes", and "they can explain the functions of the derivational suffixes (Students are not asked to memorize derivational suffixes, but the functions of them are being tried to be implicated. It is being tried to make students grasp the logic of the word derivation.)", "students can distinguish the functions of the inflectional suffixes (Inflectional suffixes of the names (plural suffixes, case suffixes, possessive suffixes, and question suffixes) are emphasized.)" (MEB, 2018).

Then the teachers of Turkish language working in middle schools are interviewed, and they were asked to give information about the topics related to suffixes taught as of the $5^{\text {th }}$ grade. Accordingly, a general frame was drawn for the suffixes that should be commonly known by the middle school students from all grades at the end of the training period. Then the researcher made a literature review in the books on morphology (Banguoğlu, 1995; Bilgegil, 2009; Eker, 2011; Ergin, 2008; Gülensoy, 2010; Karaağaç, 2012; Karahan, 2005; Korkmaz, 2009), and he prepared a list of suffixes that are reported to be frequently used in the aforesaid references with common view. He transformed this list consisting of 70 suffixes into an expert opinion form by enriching the list through examples, and he sent it to 9 academicians having Ph.D. degree or higher titles and to 5 teachers of the Turkish language. The responses of the interviewees were analyzed through Lawshe technique, and the suffixes getting 0.51 or more scores were included in the test to be developed. Considering the results obtained in the research conducted by Karadağ and Kurudayığlu (2010) for the purpose of determining the derivational suffixes that can be used by elementary school students, derivational suffixes prepared through expert opinions were compared to the aforesaid results, and it was decided to include 32 derivational and 13 inflectional suffixes. These suffixes are given in the table below: 
Table 3. Suffixes Evaluated in the Morphological Awareness Test

\begin{tabular}{|c|c|c|c|c|c|}
\hline \multicolumn{4}{|c|}{ Derivational Suffixes } & \multicolumn{2}{|c|}{ Inflectional Suffixes } \\
\hline$+\mathrm{Ar} /+(\mathrm{s}) \mathrm{Ar}$ & $+(\mathrm{I}) \mathrm{ncI} /+(\mathrm{U}) \mathrm{ncU}$ & - GAn & $-\mathrm{n} /-(\mathrm{I}) \mathrm{n} /-(\mathrm{U}) \mathrm{n}$ & $-\mathrm{A}$ & $-\mathrm{I} /-\mathrm{U}$ \\
\hline$+\mathrm{CA}$ & $+\mathrm{sAl}$ & $-\mathrm{GI}$ & $\begin{array}{c}-\mathrm{tI} / \text { - } \mathrm{tU} / \text { / - (I)ntI / - } \\
\text { (U)ntU }\end{array}$ & $-\mathrm{DA}$ & -DAn \\
\hline$+\mathrm{CI} /+\mathrm{CU}$ & $+\mathrm{sIz} /+\mathrm{sUz}$ & -GIn /-GUn & 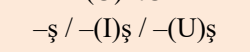 & -In/-Un/-nIn/-nUn & -im \\
\hline$+\mathrm{Clk} /+\mathrm{CUk}$ & $-(\mathrm{y}) \mathrm{AcAk}$ & $-\mathrm{I} /-\mathrm{U}$ & $+\mathrm{Al}$ & -(I)m/-(U)m & -(I)n/-(U)n \\
\hline +DAş & $-\mathrm{Ak}$ & $-(\mathrm{y}) \mathrm{IcI} /-(\mathrm{y}) \mathrm{UcU}$ & +1 & $-\mathrm{I} /-\mathrm{sI} / \mathrm{-sU}$ & (I)mIz/-(U)mUZ \\
\hline$+1 \mathrm{I} /+1 \mathrm{U}$ & $-c ̧$ & $-\mathrm{k} /-(\mathrm{I}) \mathrm{k} /-(\mathrm{U}) \mathrm{k}$ & $+1 \mathrm{~A}$ & -(I)nIz/-(U)nUz & 1ArI \\
\hline$+1 \mathrm{Ik} /+1 \mathrm{Uk}$ & $-\mathrm{gA}$ & $-\mathrm{m} /-(\mathrm{I}) \mathrm{m} /-(\mathrm{U}) \mathrm{m}$ & $+1 \mathrm{An}$ & $-1 \mathrm{Ar}$ & \\
\hline$+(\mathrm{I}) \mathrm{msI} /$ +(U)msU & -gAç & $-\mathrm{mAn}$ & $+1 \mathrm{Ass}$ & & \\
\hline
\end{tabular}

3 questions were written in the type of gap-filling exercise in order to measure the information and awareness related to each suffix, and these questions were posed to 2 specialist academicians in order to get their expert opinions. Subsequent to the examinations, the questions were put into the final form in line with the suggestions of the experts, and experimental tests were performed on three students from each grade. Since no problem was encountered during the testing process in terms of duration and comprehensibility, the MA Test was pre-implemented with the participation of the students from different grades in order to perform the item analyses of the test. The preliminary test was performed with the participation of 92 students from the $5^{\text {th }}$ grade, 98 students from the $6^{\text {th }}$ grade, 94 students from $7^{\text {th }}$ and 102 students from the $8^{\text {th }}$ grade. The item difficulty index (pj), item discrimination index (rjx) and test reliability coefficient (KR-20) were calculated with the analysis of the scores obtained by the students at the end of the pre-implementation. According to the results, the items with a difficulty index other than $0.30-0.90$ and a distinctive index lower than .30 were excluded from the test. The analyses revealed that the MA test consisting of the remaining items had a reliability score of 0.81 for the $5^{\text {th }}$ grade, 0.85 for the $6^{\text {th }}$ grade, 0.88 for the $7^{\text {th }}$ grade and 0.89 for the $8^{\text {th }}$ grade. The difficulty average of the test was determined to be 0.46 for the $5^{\text {th }}$ grade, 0.51 for the $6^{\text {th }}$ grade, 0.57 for the $7^{\text {th }}$ grade and 0.62 for the $8^{\text {th }}$ grade. Accordingly, it can be said that the MA test is moderately difficult and that it has a high rate of reliability. Consequently, the MA test consists of 90 questions in total, in which 2 questions are asked for the measurement of each suffix. The highest number of correct answers in this test is 90.1 .11 points were scored for each correct answer in the calculation of the total score, and the results were evaluated on the scale of 100 points. Accordingly, 0-44 points were classified as very low scores, 45-54 as low scores, 55-69 as mean scores, 70-84 as high scores, and 85100 as very high scores. The following table shows some of the questions in the morphological awareness test:

Table 4. Examples from the Questions in the Morphological Awareness Test

$>$ Dedemin yayladaki evi __ ağaçtan___ yapılmış. Evin tüm malzemesi ahşaptan seçilmiş. Bence bu ev doğaya saygılı bir ev şekilde inşa edildiği için harika. (A ğaç)

> Sanki dünyadaki bütün ___ kușlar___ burada toplanmış gibi sonbahar geldiğinde sığırcık sürüleri gökyüzünü kaplar. (kuş)

Evden çıkmadan önce kapıyı mutlaka ___ kilitle___ _ (kilit)

$>$ En başarılı_yönetmen ö_ülünü bu yıl da kimseye bırakmadı. Bu onun çektiği filmler sayesinde kazandığı üçüncü ödül oldu. (yönetmek)

Artık uzaktaki yazıları okumakta zorlanıyorum. Bir göz doktoruna gitsem iyi olacak. (Gözlükçülük)

$>$ Et, süt, yumurta, peynir gibi hayvanlardan elde edilen gıdaların kaliteli olmasını istiyorsak onlara besin değeri yüksek kaliteli yemler yedirmeliyiz. (besleyici) 


\subsubsection{Reading Comprehension Tests}

The pre-implementation of the test consisting of 59 questions and prepared by Bozpolat (2012) for the evaluation of reading comprehension skills in the 5th-grade students was realized with the participation of 200 students, and the mean difficulty index was calculated as 0.59 while the KR-20 value was found to be 0.90 . Accordingly, it can be said that the achievement test is moderately difficult and that it has a high rate of reliability. The discrimination index of the items ranges from 0.93 to 0.32 . The highest number of correct answers is 59 for this test. 1.7 points were scored for each correct answer, and the results were evaluated on the scale of 100 points. In this context, 0-44 points were classified as very low scores, 45-54 as low scores, 55-69 as mean scores, 70-84 as high scores, and $85-100$ as very high scores.

The mean discrimination index was calculated as 0.45 in the first 15-question section of the test comprising two different texts and developed by Ürün Karahan (2015) for the measurement of the reading comprehension skills in the 6th-grade students. The difficulty index of the aforesaid section was found to be 0.33 while Cronbach $\alpha$ internal consistency coefficient was measured as 0.73 . The discrimination index of the 20-question section was calculated as 0.56 , mean difficulty index as 0.49 , and Cronbach $\alpha$ internal consistency coefficient as 0.88. Accordingly, it can be said that the achievement test is moderately difficult and that it has a high rate of reliability. The highest number of correct answers is 35 for this test. 2.86 points were scored for each correct answer, and the results were evaluated on the scale of 100 points. Accordingly, 0-44 points were classified as very low scores, 45-54 as low scores, 55-69 as mean scores, 70-84 as high scores, and 85-100 as very high scores.

The pre-implementation of the test consisting of 36 questions and prepared by Epçaçan (2010) for the evaluation of reading comprehension skills in the 7th-grade students was realized with the participation of 150 students, and the mean difficulty index of the test was calculated as 0.50 while the KR-20 reliability coefficient was found to be 0.85 . Accordingly, it can be said that the achievement test is moderately difficult and that it has a high rate of reliability. The discrimination index of the question items ranges from 0.25 to 0.68 . The highest number of correct answers is 36 for this test. 2.78 points were scored for each correct answer, and the results were evaluated on the scale of 100 points. Accordingly, 0-44 points were classified as very low scores, 45-54 as low scores, 55-69 as mean scores, 70-84 as high scores, and 85-100 as very high scores.

The mean difficulty index was calculated as 0.50 and the KR-20 value was found to be 0.79 in the test consisting of 25 questions and developed by Girgin (2012) for the measurement of the reading comprehension skills in the 8th-grade students. When these scores are taken into consideration, it is seen that the test is moderately difficult and reliable. The difficulty levels of the items in the test range from 0.24 to 0.83 . The highest number of correct answers is 25 for this test. 4 points were scored for each correct answer, and the results were evaluated on the scale of 100 points. Accordingly, 0-44 points were classified as very low scores, 45-54 as low scores, 55-69 as mean scores, 70-84 as high scores, and 85-100 as very high scores.

\subsection{Data collection}

The data of this study were collected from the $5^{\text {th }}, 6^{\text {th }}, 7^{\text {th }}$ and $8^{\text {th }}$ grade students receiving education in 70 different classes in 12 different middle schools between 2016 and 2018. The reading comprehension test and morphological information and awareness test were performed on two consecutive days during the process of data collection, and the students were informed about the study before the tests. The reading comprehension tests were administered to each grade separately, and the students responded only to the questions prepared for their own grade levels. In the morphological awareness test, the students at all grade levels answered a 90-question test evaluating their morphological awareness and knowledge. 


\subsection{Data analysis}

The data obtained by means of measuring instruments were coded and computerized, then they were analyzed through SPSS package program. Firstly, it was examined whether the data were normally distributed so that the necessary analyses could be determined in order to achieve the purpose of the research. The coefficients of skewness and kurtosis of the data were analyzed for this purpose, and the Kolmogorov-Smirnov test was used by taking the sample size into consideration. The following table shows the results of the normal distribution analyses for all grades:

Table 5. Normality Statistics of the Reading Comprehension and Morphological Awareness Tests

\begin{tabular}{clcccccccc}
\hline Grades & $\begin{array}{l}\text { Test } \\
\text { Type }\end{array}$ & $\mathbf{N}$ & $\overline{\boldsymbol{X}}$ & $\mathbf{S s}$ & $\begin{array}{c}\text { Coefficient of } \\
\text { Skewness }\end{array}$ & $\begin{array}{c}\text { Skewness Standard } \\
\text { Error }\end{array}$ & $\begin{array}{c}\text { Coefficient of } \\
\text { Kurtosis }\end{array}$ & $\begin{array}{c}\text { Kurtosis } \\
\text { Standard } \\
\text { Error }\end{array}$ & $\mathbf{p}^{*}$ \\
\hline \multirow{2}{*}{$5^{\text {th }}$ Grade } & RC & \multirow{2}{*}{396} & 60.59 & 21.05 & 0.217 & 0.123 & -1.199 & 0.245 & .00 \\
& MA & & 48.51 & 6.44 & 0.167 & 0.123 & -1.084 & 0.245 & .00 \\
\multirow{2}{*}{$6^{\text {th }}$ Grade } & RC & \multirow{2}{*}{392} & 64.12 & 18.73 & -0.155 & 0.123 & -0.890 & 0.246 & .00 \\
& MA & & 54.31 & 10.41 & 0.261 & 0.123 & -1.056 & 0.246 & .00 \\
$7^{\text {th }}$ Grade & RC & \multirow{2}{*}{388} & 66.82 & 18.09 & -0.266 & 0.124 & -0.894 & 0.247 & .00 \\
& MA & & 61.72 & 11.82 & 0.039 & 0.124 & 0.100 & 0.247 & .00 \\
$8^{\text {th }}$ Grade & RC & \multirow{2}{*}{385} & 68.77 & 15.44 & -0.074 & 0.124 & -0.744 & 0.248 & .00 \\
& MA & & 67.79 & 11.49 & 0.180 & 0.124 & -1.127 & 0.248 & .00 \\
\hline
\end{tabular}

*p>.05 significant $\quad$ RC: Reading Comprehension MA: Morphological Awareness

When the coefficient of skewness is divided by the standard error of the skewness and the coefficient of kurtosis is divided by the standard error of the kurtosis, the results between the values of -1.96 and +1.96 are regarded as a sign of the normal distribution (Can, 2017, p. 85). When the calculations made on the data in Table 5 are taken into consideration, it is seen that the values are not in the specified range. Kolmogorov-Smirnov test was used in order to confirm this result. The Kolmogorov-Smirnov test is based on the principle specifying whether the relevant data conform to the normal probability distribution of a defined population (Can, 2017, p. 88). The fact that the p-value calculated according to this test is greater than $\alpha=.05$ is considered as the evidence demonstrating that the scores are of normal distribution at this level of significance (Mertler and Vannatta, 2005). As seen in the table, the $\mathrm{p}$ values obtained at all grade levels were smaller than the normally accepted values. Accordingly, it was determined that the relevant scores were not normally distributed. For this reason, it was decided to use the non-parametric tests in the analysis of data. When scale is likert type and levels of likert are 5 and above in quantitative researches, it is expected to look for normal distribution in order to get analyzing results correctly. However, especially in achievement tests, the probability of abnormal distribution of scores is quite high. Accordingly, it is not an accurate approach to extract data in order to get normal distribution. Because, it is a natural and expected result that the data show a heterogeneous distribution due to the characteristics of the achievement tests. For these reasons, it was found more appropriate to use non-parametric tests in analyzing data depending on abnormal distribution of scores.

The Mann-Whitney U test was used to determine whether the gender has an effect on the reading comprehension and morphological awareness through the calculations of arithmetic average and descriptive statistics in the identification of reading comprehension and morphological awareness levels. The Mann-Whitney U test is used to determine whether the scores obtained from two unrelated samples differ significantly from each other, in other words, whether two unrelated groups have similar distributions in the population in terms of the relevant variables (Büyüköztürk, 2017, p. 165). 
This test is a non-parametric alternative to the t-test for independent samples, and, unlike parametric tests, it compares the medians rather than the average of the two groups (Pallant, 2016, p. 249).

Correlation analysis was performed in order to reveal the existence of a relationship between the level of morphological awareness and the success in reading comprehension. Correlation analysis is used to determine whether there is dependence between two variables measured at the interval and ratio level, and to define the strength and direction of the aforesaid linear relationship, if any. (Pallant, 2016, p. 144; Yazıcıŏlu and Erdoğan, 2017, p. 335).

In addition to these analyses, the Kruskal Wallis test was preferred so as to identify whether the scores of reading comprehension and morphological awareness differed significantly among the grades. The Kruskal-Wallis test enables to evaluate whether two or more unrelated sample averages differ significantly from each other. The analysis is based on the comparison of the scores belonging to $\mathrm{k}$ numbered samples regarding one dependent variable. This test can be used as an alternative to one-way analysis of variable since it does not require the assumptions of normal distribution and variance equality in each subgroup based on the group variable of the scores (Büyüköztürk, 2017, p. 168).

The Mann Whitney U Test was chosen to determine which grade levels differed significantly in terms of the scores of reading comprehension and morphological awareness in the middle-school students.

\section{Results}

The findings are presented respectively in line with the research questions of this study which aim to determine the reading comprehension and morphological awareness levels in middle school students, to identify whether the gender has an impact on these two notions, and to reveal whether there is a significant relationship between reading comprehension and morphological awareness.

Table 6 demonstrates the scores that the students obtained in the reading comprehension test prepared according to their levels in line with the research question indicating "What are the levels of reading comprehension in the $5^{\text {th }}, 6^{\text {th }}, 7^{\text {th }}$ and $8^{\text {th }}$ grade students" selected for the determination of the reading comprehension levels of the middle school students participating in the study:

Table 6. Descriptive Results Related to the Reading Comprehension Scores

\begin{tabular}{ccccc}
\hline Grades & N & $\overline{\boldsymbol{X}}$ & Point & Level of Reading Comprehension \\
\hline $5^{\text {th }}$ Grade & 396 & 35.65 & 60.59 & Middle \\
$6^{\text {th }}$ Grade & 392 & 22.42 & 64.12 & Middle \\
$7^{\text {th }}$ Grade & 388 & 24.01 & 66.82 & Middle \\
$8^{\text {th }}$ Grade & 385 & 17.21 & 68.77 & Middle \\
\hline
\end{tabular}

According to Table 6, the average scores of 1561 middle-school students selected as the sample in grade-based reading comprehension tests are given respectively as follows: 35.65 in 59 questions for the $5^{\text {th }}$ grade students, 22.42 in 35 questions for the $6^{\text {th }}$ grade students, 24.01 in 36 questions for the $7^{\text {th }}$ grade students and 17.21 in 25 questions for the $8^{\text {th }}$ grade students. Accordingly, the obtained scores correspond to 60.59 for the $5^{\text {th }}$ grade students, 64.12 for the $6^{\text {th }}$ grade students, 66.82 for the $7^{\text {th }}$ grade students and 68.77 for the $8^{\text {th }}$ grade students in the 100-point rating scale. These findings demonstrate that the reading comprehension skills of the students in all grades are at a medium level. 
Although the levels of reading comprehension in $5^{\text {th }}, 6^{\text {th }}, 7^{\text {th }}$ and $8^{\text {th }}$ grade students were found to be moderate according to the rating scale, it was seen that there was a steady increase in the mean scores of the reading comprehension from the $5^{\text {th }}$ grade to the $8^{\text {th }}$ grade when the mean scores of the students were carefully examined. Kruskal Wallis test was performed in line with the research question indicating "Do the levels of reading comprehension in middle school students differ according to their grades?" in order to determine whether the above-mentioned increase created a significant difference depending on the grade level, and the result of the analysis is given below:

Table 7. The Results of Kruskal Wallis Test Regarding the Reading Comprehension Scores

\begin{tabular}{cccccc}
\hline Grades & $\mathbf{N}$ & SO & $\mathbf{x}^{\mathbf{2}}$ & Sd & $\mathbf{p}^{*}$ \\
\hline $5^{\text {th }}$ Grade & 396 & 679.09 & & & \\
$6^{\text {th }}$ Grade & 392 & 758.52 & 37.737 & 3 & .000 \\
$7^{\text {th }}$ Grade & 388 & 827.48 & & & \\
$8^{\text {th }}$ Grade & 385 & 861.87 & & & \\
\hline$*^{*}<05$ significant & & & & & \\
\hline
\end{tabular}

$* \mathrm{p}<.05$ significant

According to the results of the Kruskal-Wallis analysis shown in Table 7, it was found out that the students in different grades also had different levels of reading comprehension and that this difference was significant $(x 2(3)=37.737 ; \mathrm{p}=.00)$. Binary comparisons were made through the Mann-Whitney $\mathrm{U}$ test, which was used to determine under which levels the aforesaid grade-based difference was observed. The results of the analysis are presented in the following table:

Table 8. Mann-Whitney U Results Regarding the Differences in Reading Scores among the Grades

\begin{tabular}{|c|c|c|c|c|c|c|}
\hline Grades & $\mathbf{N}$ & Compared Grades & $\mathbf{N}$ & $\mathbf{U}$ & $\mathbf{z}$ & $\mathbf{p}^{*}$ \\
\hline \multirow{3}{*}{$5^{\text {th }}$ Grade } & \multirow{3}{*}{396} & $6^{\text {th }}$ Grade & 392 & 69338.0 & -2.592 & .010 \\
\hline & & $7^{\text {th }}$ Grade & 388 & 63279.0 & -4.273 & .000 \\
\hline & & $8^{\text {th }}$ Grade & 385 & 57697.0 & -5.882 & .000 \\
\hline \multirow{2}{*}{$6^{\text {th }}$ Grade } & \multirow{2}{*}{392} & $7^{\text {th }}$ Grade & 388 & 68423.0 & -2.424 & .015 \\
\hline & & $8^{\text {th }}$ Grade & 385 & 65996.0 & -3.027 & .002 \\
\hline $7^{\text {th }}$ Grade & 388 & $8^{\text {th }}$ Grade & 385 & 71553.0 & -1.011 & .312 \\
\hline
\end{tabular}

*p<.05 significant

According to the results of the Mann-Whitney $\mathrm{U}$ test in Table 8, it is understood that the eighth grade students were more successful than the seventh, sixth and fifth grade students, that the seventh grade students were more successful than the sixth and fifth grade students and that the sixth grade students were more successful than the fifth grade students in terms of reading comprehension. Accordingly, the success in reading comprehension increases as the grade levels elevate.

The scores of the students were analyzed by means of the Mann-Whitney $U$ test within the framework of the research question indicating "Do the levels of reading comprehension in middle school students differ according to gender?" in order to determine whether the gender had an impact on the achievement scores of the students who participated in the research, and the results are presented in the following table: 
Table 9. Mann-Whitney U Test Results Regarding the Effect of Gender on Reading Comprehension Scores

\begin{tabular}{|c|c|c|c|c|c|c|c|c|}
\hline Grades & Gender & $\mathbf{N}$ & $\overline{\bar{X}}$ & MR & SR & $\mathbf{U}$ & $\mathbf{z}$ & $\mathbf{p}^{*}$ \\
\hline \multirow{2}{*}{$5^{\text {th }}$ Grade } & Male & 203 & 59.28 & 191.31 & 38835.5 & \multirow{2}{*}{18129.5} & \multirow{2}{*}{-1.283} & \multirow{2}{*}{.200} \\
\hline & Female & 193 & 61.98 & 206.06 & 39770.5 & & & \\
\hline \multirow{2}{*}{$6^{\text {th }}$ Grade } & Male & 194 & 62.37 & 185.98 & 36081.0 & \multirow{2}{*}{17166.0} & \multirow{2}{*}{-1.821} & \multirow{2}{*}{.069} \\
\hline & Female & 198 & 65.82 & 206.80 & 40947.0 & & & \\
\hline \multirow{2}{*}{$7^{\text {th }}$ Grade } & Male & 187 & 64.91 & 180.54 & 33760.5 & \multirow{2}{*}{16182.5} & \multirow{2}{*}{-2.368} & \multirow{2}{*}{.018} \\
\hline & Female & 201 & 68.60 & 207.49 & 41705.5 & & & \\
\hline \multirow{2}{*}{$8^{\text {th }}$ Grade } & Male & 199 & 66.73 & 177.22 & 35266.5 & \multirow{2}{*}{15366.5} & \multirow{2}{*}{-2.886} & \multirow{2}{*}{.004} \\
\hline & Female & 186 & 70.95 & 209.88 & 39038.5 & & & \\
\hline
\end{tabular}

When the data in Table 9 were examined, it was found out that there was a difference of 2.7 points in favor of the female students as seen in the comparison of the mean scores of reading comprehension in the $5^{\text {th }}$ grade male and female students; however, this difference was not statistically significant $(\mathrm{p}=$ $0.20)$. The difference in the mean achievement scores between male and female students was recorded as $3.45(\mathrm{p}=0.69)$ in the $6^{\text {th }}$ grade, $3.69(\mathrm{p}=0.018)$ in the $7^{\text {th }}$ grade, and $4.22(\mathrm{p}=0.004)$ in the $8^{\text {th }}$ grade, and it was understood that these differences were statistically significant. The graphic given below demonstrates the distribution of reading comprehension scores in the students from all grades participating in the study, in other words, the difference between the success rates of the male and female students from different grades in the field of reading comprehension.

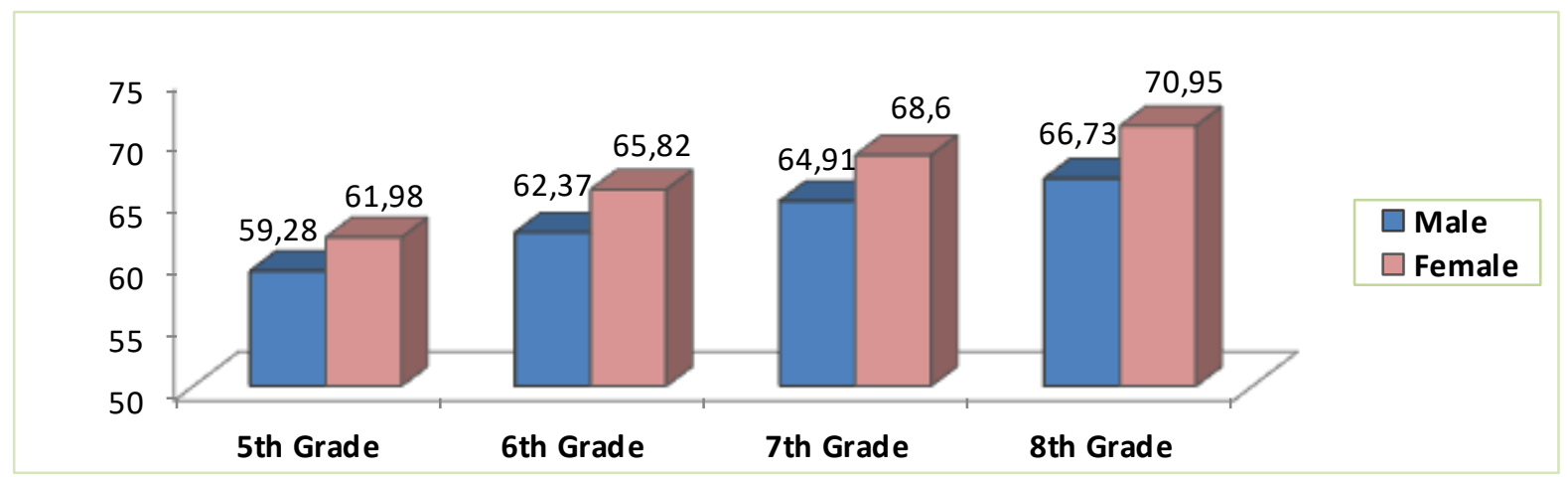

Graph 1. Reading Comprehension Scores According to Gender

When the findings in Table 9 and Graph 1 are examined, it can be said that the female students were more successful than the male students in terms of reading comprehension and that the issue of gender creates a significant difference on the success in reading comprehension in all grade levels.

Table 10 presents the scores of the students in the morphological awareness test that has been prepared in line with the research question indicating "What are the levels of morphological awareness in the $5^{\text {th }}, 6^{\text {th }}, 7^{\text {th }}$ and $8^{\text {th }}$ grade students? " in order to determine the middle school students' levels on the subject of morphological awareness: 
Table 10. Descriptive Results on Morphological Awareness Scores

\begin{tabular}{ccccc}
\hline Grades & $\mathbf{N}$ & $\overline{\boldsymbol{X}}$ & Point & Level of Morphological Awareness \\
\hline $5^{\text {th }}$ Grade & 396 & 43.71 & 48.51 & Low \\
$6^{\text {th }}$ Grade & 392 & 48.91 & 54.31 & Low \\
$7^{\text {th }}$ Grade & 388 & 55.54 & 61.72 & Middle \\
$8^{\text {th }}$ Grade & 385 & 61.15 & 67.79 & Middle \\
\hline
\end{tabular}

According to Table 10, the mean scores obtained from the morphological awareness achievement test of 1561 middle school students in different grades were given respectively as follows: 43.71 for the fifth-grade students, 48.91 for the sixth-grade students, 55.54 for the seventh-grade students and 61.15 for the eighth-grade students. Accordingly, the scores listed above correspond to 48.51 for the fifth grade, 54.31 for the sixth grade, 61.72 for the seventh grade and 67.79 for the eighth grade in the 100-point rating scale. These findings indicate that the students in the fifth and sixth grades have low morphological awareness while the students in the seventh and eighth grade have moderate morphological awareness.

When the mean scores of the students in the $5^{\text {th }}, 6^{\text {th }}, 7^{\text {th }}$ and $8^{\text {th }}$ grades obtained from the morphological awareness test are examined, it is seen that the scores of morphological awareness show a continuous increase from the $5^{\text {th }}$ grade to the $8^{\text {th }}$ grade. Kruskal Wallis test was performed in line with the research question indicating "Do the levels of morphological awareness in middle school students differ according to their grades?" in order to determine whether the above-mentioned increase created a significant difference depending on the grade level, and the result of the analysis is given below:

Table 11. Kruskal Wallis Test Results on the Morphological Awareness Scores

\begin{tabular}{cccccc}
\hline Grades & $\mathbf{N}$ & SO & $\mathbf{x}^{\mathbf{2}}$ & $\mathbf{S d}$ & $\mathbf{p}^{*}$ \\
\hline $5^{\text {th }}$ Grade & 396 & 425.61 & & & \\
$6^{\text {th }}$ Grade & 392 & 659.15 & 537.740 & 3 & .000 \\
$7^{\text {th }}$ Grade & 388 & 927.51 & & & \\
$8^{\text {th }}$ Grade & 385 & 1122.95 & & & \\
\hline
\end{tabular}

$* \mathrm{p}<.05$ significant

When the results in Table 11 are examined, It was determined that students in the $5^{\text {th }}, 6^{\text {th }}, 7^{\text {th }}$ and $8^{\text {th }}$ grade were at different levels in terms of morphological awareness and that this difference was statistically significant $(x 2(3)=537.740, \mathrm{p}=.00)$. The Mann-Whitney U test was performed in order to determine the extent to which this significant difference occurred among the students at different grade levels, and binary comparisons were made between the grades through this test. The results of the analysis are given in the following table: 
Table 12. Mann-Whitney U Results Regarding the Score Differences among the Grades in terms of Morphological Awareness

\begin{tabular}{ccccccc}
\hline Grades & $\mathbf{N}$ & Compared Grades & $\mathbf{N}$ & $\mathbf{U}$ & $\mathbf{z}$ & $\mathbf{p}^{*}$ \\
\hline \multirow{2}{*}{$5^{\text {th }}$ Grade } & 396 & $6^{\text {th }}$ Grade & 392 & 53442.0 & -7.573 & .000 \\
& & $7^{\text {th }}$ Grade & 388 & 25974.0 & -16.048 & .000 \\
\multirow{2}{*}{$6^{\text {th }}$ Grade } & 392 & $8^{\text {th }}$ Grade & 385 & 10521.5 & -20.855 & .000 \\
$7^{\text {th }}$ Grade & 388 & $7^{\text {th }}$ Grade & 388 & 48891.5 & -8.635 & .000 \\
$*^{*}$ p $<.05$ significant & $8^{\text {th }}$ Grade & 385 & 30678.0 & -14.321 & .000 \\
& & $8^{\text {th }}$ Grade & 385 & 53530.5 & -6.819 & .000 \\
\hline
\end{tabular}

$* \mathrm{p}<.05$ significant

According to the results of the Mann-Whitney $\mathrm{U}$ test in Table 12, it is understood that the eighth grade students were more successful than the seventh, sixth and fifth grade students, that the seventh grade students were more successful than the sixth and fifth grade students and that the sixth grade students were more successful than the fifth grade students in terms of morphological awareness. Accordingly, the success in morphological awareness increases as the grade levels elevate. In other words, as the students grow up and continue their education at higher grades, they become more equipped with morphological awareness.

The scores of the students were analyzed by means of the Mann-Whitney $U$ test within the framework of the research question indicating "Do the levels of morphological awareness in middle school students differ according to gender?" in order to determine whether the gender had an impact on the achievement scores of the students who participated in the research, and the results are presented in the following table:

Table 13. Mann-Whitney U Results Regarding the Impact of Gender on Morphological Awareness Scores

\begin{tabular}{|c|c|c|c|c|c|c|c|c|}
\hline Grades & Gender & $\mathbf{N}$ & $\bar{X}$ & MR & SR & $\mathbf{U}$ & $\mathbf{z}$ & $\mathbf{p}^{*}$ \\
\hline \multirow{2}{*}{$5^{\text {th }}$ Grade } & Male & 203 & 47.99 & 190.82 & 38736.5 & \multirow{2}{*}{18030.5} & \multirow{2}{*}{-1.371} & \multirow{2}{*}{.170} \\
\hline & Female & 193 & 49.05 & 206.58 & 39869.5 & & & \\
\hline \multirow{2}{*}{$6^{\text {th }}$ Grade } & Male & 194 & 52.24 & 175.44 & 34034.5 & \multirow{2}{*}{15119.5} & \multirow{2}{*}{-3.645} & \multirow{2}{*}{.000} \\
\hline & Female & 198 & 56.34 & 217.14 & 42993.5 & & & \\
\hline \multirow{2}{*}{$7^{\text {th }}$ Grade } & Male & 187 & 59.43 & 174.99 & 32723.0 & \multirow{2}{*}{15145.0} & \multirow{2}{*}{-3.307} & \multirow{2}{*}{.001} \\
\hline & Female & 201 & 63.86 & 212.65 & 42743.0 & & & \\
\hline \multirow{2}{*}{$8^{\text {th }}$ Grade } & Male & 199 & 65.53 & 171.69 & 34165.5 & \multirow{2}{*}{14265.5} & \multirow{2}{*}{-3.889} & \multirow{2}{*}{.000} \\
\hline & Female & 186 & 70.21 & 215.80 & 40139.5 & & & \\
\hline
\end{tabular}

$* \mathrm{p}<.05$ significant

When the data in Table 13 were examined, it was found out that there was a difference of 1.06 points in favor of the female students between the mean scores of morphological awareness in the $5^{\text {th }}$ grade male and female students; however, this difference was not statistically significant $(p=0.170)$. The difference in the mean achievement scores between male and female students was recorded as 4.1 $(\mathrm{p}=0.00)$ in the $6^{\text {th }}$ grade, $4.43(\mathrm{p}=0.001)$ in the $7^{\text {th }}$ grade, and $4.68(\mathrm{p}=0.000)$ in the $8^{\text {th }}$ grade, and it was understood that these differences were statistically significant. 


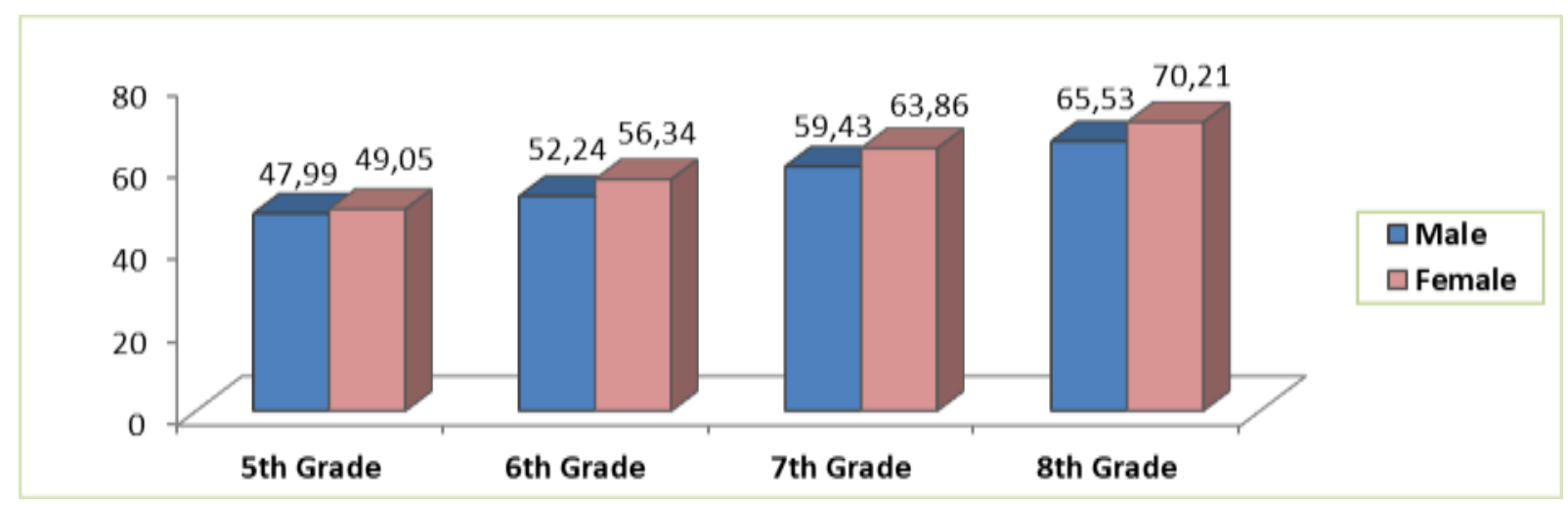

Graph 2. Morphological Awareness Scores According to Gender

When the findings in Table 13 and Graph 2 are examined, it can be said that the female students were more successful than the male students in terms of morphological awareness and that the issue of gender creates a significant difference on the success in morphological awareness in all grade levels.

The scores obtained by the students in the tests of reading comprehension and morphological awareness were examined through the correlation analysis in line with the research question indicating "Is there a significant relationship between the levels of reading comprehension and the levels of morphological awareness in the $5^{\text {th }}, 6^{\text {th }}, 7^{\text {th }}$ and $8^{\text {th }}$ grade students?" in order to find out whether there is a reciprocal relationship between the reading comprehension and morphological awareness, which is one of the main topics that the present research aims to reveal. The results of the analysis are shown in the table below:

Table 14. Correlation Analysis Regarding the Scores of Reading Comprehension and Morphological Awareness

\begin{tabular}{ccccc}
\hline Grades & Factors & $\mathbf{N}$ & $\mathbf{r}$ & $\mathbf{p}^{*}$ \\
\hline $5^{\text {th }}$ Grade & & 396 & .691 & .00 \\
$6^{\text {th }}$ Grade & Reading Comprehension - Morphological Awareness & 392 & .731 & .00 \\
$7^{\text {th }}$ Grade & & 388 & .735 & .00 \\
$8^{\text {th }}$ Grade & & 385 & .785 & .00 \\
All Grades & & 1561 & .726 & .00 \\
\hline$*$ p $<.05$ significant & & & &
\end{tabular}

As shown in Table 14, it was found out that there was a significant positive correlation between the reading comprehension and morphological awareness at all grade levels $(\mathrm{r}=.726, \mathrm{p}=0.00)$. The correlation value (r) of at least .50 and above indicates that the studied relationship is correctly represented (Fraenkel et al., 2012). The strength of this relationship was calculated as $r=.691$ in the $5^{\text {th }}$ grade, $r=.691$ in the $6^{\text {th }}$ grade, $r=735$ in the $7^{\text {th }}$ grade and $r=735$ in the $8^{\text {th }}$ grade. "The values between 0,70 and 1,00 can be considered as high-level relationship while the values between 0,70 and 0,30 may be accepted as medium-level relationship and the values between 0,30 and 0,00 as a low-level relationship" (Büyüköztürk, 2009, p.42). Accordingly, it can be said that there is a high-level relationship between the reading comprehension and morphological awareness. However, it should be remembered that this link is not a cause and effect relationship. Because correlation is an indicator of the relationship between two variables, but it does not indicate that one variable is the cause of the other (Pallant, 2016, p.140). In other words, it cannot be claimed that a high level of reading comprehension in the students leads to a high morphological awareness or a high level of 
morphological awareness leads to a high level of reading comprehension. Nevertheless, it can be remarked that the students with a high level of reading comprehension also have a high level of morphological awareness. The findings obtained from this analysis show that the students with good reading comprehension skills also have higher morphological awareness.

\section{Conclusion, Discussion and Suggestions}

This study has been carried out in the relational screening model in order to determine the levels of reading comprehension and morphological awareness in middle school students and to examine the dimensions of these two concepts by illustrating the possible existence of a relationship between them, and the results of the study are given as follows:

It has been understood that the $5^{\text {th }}, 6^{\text {th }}, 7^{\text {th }}$ and $8^{\text {th }}$ grade middle school students selected as the sample of the study were at the intermediate level in terms of reading comprehension skills. There are 6 previous studies in the literature in which the reading comprehension level was found to be intermediate in the $5^{\text {th }}$ grade students, which is similar to our study (Karabay and Kayıran, 2010; Karakuş Tayşi, 2007; Özder et al., 2012; Sidekli, 2005; Yıldırım et al., 2010; Yıldız, 2010). There are also other studies in which the level of comprehension at the $5^{\text {th }}$ grade was found to be higher (Çam, 2006; Çiftçi, 2007) and lower (Anılan, 2004) although the number of such studies is limited. In two studies on the reading comprehension levels of the $6^{\text {th }}$ grade students (Göktaş and Gürbüztürk, 2012; Sert, 2010), the aforesaid level was found to be intermediate, which is similar to the findings of our study. On the other hand, another study revealed that the reading comprehension skills of the $6^{\text {th }}$ grade students were at a low level (İşcan, 2009). There are two studies in which the reading comprehension levels of the $7^{\text {th }}$ grade students were found to be intermediate (Ateş, 2008; Kurnaz, 2018), and one study in which the above-mentioned level was recorded to be low (Bayraktar, 2017). There are two studies in which the reading comprehension levels of the $8^{\text {th }}$ grade students were found to be intermediate, which is similar to the findings of our study (Balc1, 2009; Gelbal, 2008). In two studies, the skills of the students were recorded to be at a low level (Karakuş Tayşi, 2007; Saracaloğlu, et al., 2011) while three studies revealed higher levels of reading comprehension in the $8^{\text {th }}$ grade students (Keleş, 2005; Sallabaş, 2008; Sanır, 2017). When the above-mentioned studies are evaluated together as a whole, it can be said that the reading comprehension skills of the students at all grades are generally at the intermediate level. At this point, the findings obtained in this study are similar to the results recorded in most of the studies in the literature. In the light of these data, it can be said that the middle school students are not at the desired level in terms of the skills and ability of reading comprehension which is a feature that totally influences the daily and educational life. The results of international studies also show that middle school students do not have sufficient skills in terms of reading comprehension. For instance, according to PISA data, it is known that the average of the correct answers given by the Turkish students is far below the general average (approximately 50\%) (Bozkurt, 2016, p. 1681).

In the study, it was also determined that there was a significant level-based difference among the $5^{\text {th }}, 6^{\text {th }}, 7^{\text {th }}$ and $8^{\text {th }}$ grade students in terms of reading comprehension level and success. It has been observed that this difference indicates higher levels of success in reading comprehension at higher grades. Mental development may become the main reason for higher success rates in reading comprehension in the students receiving education at higher grades. The linguistic skills, worldviews, perceptual capacity and discernment of 11-year-old individuals will make positive progress as long as there is not an unexpected developmental problem. At this point, it is quite normal that reading comprehension skills develop with age just like other knowledge and skills. Since this conclusion 
corresponds to the natural flow of life and the nature of human and language development, it also confirms the validity of the findings in this study.

The study has also illustrated that the achievement scores and levels of the middle school students in terms of reading comprehension significantly differed according to gender. Accordingly, it has been seen that the female students got higher scores than the male students in the $5^{\text {th }}, 6^{\text {th }}, 7^{\text {th }}$ and $8^{\text {th }}$ grades. As a result of the analyses performed within the scope of this study, it has been determined that the difference in scores between the female and male students in the $6^{\text {th }}, 7^{\text {th }}$ and $8^{\text {th }}$ grades was statistically significant and that the score difference in favor of the female students in the $5^{\text {th }}$ grade was not statistically significant. Female students were concluded to be more successful than male students in most of the studies carried out in order to evaluate whether the gender has an impact on the reading comprehension skills of the students in Turkey and consisting of the students in the $5^{\text {th }}$ grade (Anilan, 2004; Çam, 2006; Çiftçi and Temizyürek, 2008; Karakuş Tayşi, 2007; Kutlu, et al., 2011; Sidekli, 2005 ), in the $6^{\text {th }}$ grade (İşcan, 2009; Sert, 2010; Yiğit, 2013), in the $7^{\text {th }}$ grade (Ateş, 2008; Bayraktar, 2017; Kurnaz, 2018) and in the $8^{\text {th }}$ grade (Balc1, 2009; Gelbal, 2008; Gündemir, 2002; Keleş, 2005; Özer Özkan and Doğan, 2013; Sallabaş, 2008; Temizyürek, 2008). There are also different studies in the literature indicating that the gender does not create a significant difference in reading comprehension skills of the students (Avcıoğlu, 2000; Göktaş and Gürbüztürk, 2012; Saracaoğlu, et al., 2011; Ürün Karahan, 2015; Yıldı, 2010). However, these studies are more limited than the ones reporting the significant impact of the gender on the reading comprehension capability of the students. In this study, it was also concluded that the female students were more successful than the male students in the same direction as the studies that represent the majority in the literature. The higher success rates of female students in most of the studies in the literature are explained through numerous reasons. Sidekli (2006) indicates that female middle school students assume more responsibilities while male students spare more time to play. In a similar manner, female students have an early mental maturation (Bacanl, 2000), their linguistic skills and abilities develop earlier than those of males; the perceptions and expectations of the teachers for the success of female students in reading comprehension lead those students to become more successful (Güngör ve Açıkgöz, 2005). In addition to this, female students reach puberty and abstract operation period earlier than male students and there are differences in the use of verbal and non-verbal linguistic skills by male and female students influencing their success in reading comprehension (Weiss, et al., 2003). In many other studies in which the female students have been found to be more successful in terms of reading comprehension, it is seen that no attempt has been made to explain the underlying cause of this situation. Instead, the researchers have only referred to other similar studies (Kuşdemir and Katranc1, 2016, p.260). The above-mentioned reasons have an impact on the higher success rates of female students in reading comprehension than the rates of male students. It is considered that only one of these reasons cannot explain the differences in the levels and success rates of the students, but that their combination can clarify these differences.

In this study, it is also aimed to determine the morphological awareness levels of middle school students. As a result of the tests and findings, it was determined that the students in the $5^{\text {th }}$ and $6^{\text {th }}$ grades had a low level of morphological awareness and that the students in the $7^{\text {th }}$ and $8^{\text {th }}$ grades had an intermediate level of morphological awareness. When the data obtained from the study are examined carefully, it is seen that the achievement scores on morphological awareness have increased steadily from the $5^{\text {th }}$ grade to the $8^{\text {th }}$ grade and that this increase a statistically significant differentiation. It is considered that the reasons for higher morphological performance in older students aged between 11 and 15 are related to the physical and mental maturation, development of linguistic skills, advancement of the awareness in language and structure, abstract thinking, and abstract operations such as dividing and combining the parts of the words and integrating them in the 
holistic sense. The results of this study also confirm this consideration by demonstrating that the 11year-old students in the $5^{\text {th }}$ grade got the in the morphological awareness achievement tests while 15year-old students in the $8^{\text {th }}$ grade got the highest scores. It has been also found out in this study that the gender caused significant differentiation in the morphological awareness levels of the students. Accordingly, it has been seen that the female students got higher scores than the male students in all grade levels included in the study. As a result of the analyses performed within the scope of this study, it has been understood that the difference in scores between the $6^{\text {th }}, 7^{\text {th }}$ and $8^{\text {th }}$ grade female students and male students was statistically significant and that the difference among the $5^{\text {th }}$ grade in favor of the female students was not statistically significant. Since this study is the first research on the morphological awareness of Turkish children, the results of the study could not be compared with any similar research on morphological awareness.

The final stage of the study has examined whether there is a relationship between the success rates of middle school students in reading comprehension and the success rates in morphological awareness. The analyses performed on the data of the study indicate the presence of a strong relationship between the success in reading comprehension and the morphological success. This relationship has been observed to be non-causal, and it has revealed that the students who are successful in reading comprehension also have success in morphological awareness. In other words, it cannot be claimed that higher success rates of the students in reading comprehension lead to higher levels of morphological awareness or vice versa. However, it can be stated that the students who are successful in reading comprehension also have higher levels of morphological awareness. At this point, it can be said that the students having lower levels of morphological knowledge and awareness also encounter certain problems in comprehending what they read while the students with higher levels of morphological awareness understand the texts more effectively. In another study carried out in the USA with the participation of 4780 students from the $3^{\text {rd }}$ grade to $10^{\text {th }}$ grade whose native language is English and having similar results with the ones obtained in this study, it has been seen that there is a strong relationship between the morphological knowledge of the students and their success in reading comprehension in all grade levels except the $10^{\text {th }}$ grade (Foorman, Petscher and Bishop, 2012). In another study performed on the $3^{\text {rd }}, 4^{\text {th }}$ and $5^{\text {th }}$ grade students in Brazil whose native language is Spanish, it has been determined that morphological awareness influences the reading comprehension process in general and that the students having better performances in terms of morphological awareness also get better scores in reading comprehension (Guimaraes et al., 2014). In the research carried out by Silva and Martins-Reis for analyzing 10 studies on the students from kindergarten to the $10^{\text {th }}$ grade whose native languages are English and Spanish, the researchers have compared the results of the studies evaluating the relationship between morphological awareness and reading comprehension, and they have reported that the students getting high scores in the morphological awareness tests also have scored high points in the reading comprehension tests (Silva and MartinsReis, 2016, p. 7). In a study investigating whether the morphological awareness and part information of the students in the $3^{\text {rd }}$ and $5^{\text {th }}$ grades have an impact on reading and comprehending morphologically complicated and difficult words, Carlisle (2000) have found out that there is a significant relationship between the structural awareness and the definition of morphologically complicated words and that the morphological awareness makes contribution to reading comprehension skills both in the $3^{\text {rd }}$ and $5^{\text {th }}$ grade students although this contribution is more evident among the $5^{\text {th }}$ graders. Katz (2004) has analyzed the impact of the morphological awareness of the 4th and $6^{\text {th }}$ grade students whose native language is English on their success in reading comprehension, and he has concluded that morphological awareness is an important predictor affecting the reading comprehension skills of both the $4^{\text {th }}$ and the $6^{\text {th }}$ grade students along with other language-related variables. Loudermill (2014) has performed a study to find out whether there is a statistically 
significant difference between the students with lower reading comprehension skills and the students with higher reading comprehension skills in terms of word formation knowledge, and he has reported that the students with higher reading comprehension skills have shown better performance during the education process for creating awareness in word formation than the students with lower reading comprehension skills. In addition, it has been detected that there is a significant relationship between the reading comprehension skills and the ability of word formation in the students having better reading comprehension skills while the same positive relationship was not observed in the group having insufficient skills in terms of reading comprehension. Curinga (2014) has investigated whether morphological awareness training given to bilingual students in adolescence has influenced their reading comprehension skills in both their native language and second language. No specific implementation was made for the students participating in the study; however, it was researched whether the morphological awareness that the participants have already influenced the reading comprehension skills of the students. At the end of the study, it has been concluded that the linguistic variables have had an important effect on the morphological awareness and that the morphological awareness has strongly contributed to the reading comprehension skills of the participants both in their native language, Spanish, and their second language (English). In another study on bilingual individuals, it has been determined that the students can transfer their morphological awareness in Chinese and Spanish to their second language, which is English, and that this transfer has created a positive impact on word reading and word learning in English (Gomez, 2009). The present study is a pioneer for the studies to be carried out on the Turkish language in terms of morphological awareness since there is no other study in the Turkish literature aiming to determine the levels of morphological awareness in middle school students, to reveal the differences in morphological awareness level among the grades and to find out whether the gender has an impact on the morphological awareness.

Individuals learn the linguistic concepts and systems in parallel with their level of maturity as of their infancy as the nature of human development, and this acquisition gives its place to the conscious learning and the development of new skills when they reach a certain age. For instance, the individuals are supposed to develop their reading comprehension skills in order to learn the decoding process that is called "reading" and to comprehend what they read after acquiring necessary words, linguistic structures, and systems. This requirement applies to all basic language skills and other linguistic skills involved in the process. The information on the structure of the language which can be termed as morphological knowledge, skill or awareness is acquired in the process of language acquisition just like other linguistic information; however, the effective use of the language cannot be ensured without an awareness-raising process in this issue. Morphological knowledge or awareness begins to develop in the early childhood (Berko, 1958), and the children start to analyze certain morphological structures of the words by realizing that they have this knowledge as time progresses (Carlisle, 2003). This morphological awareness does not develop only as a result of the natural development and maturation in children or the exposure to a spoken language. A deliberate and planned training process is needed for the acquisition of such awareness. The studies indicating that morphological awareness training contributes significantly to the linguistic skills and vocabulary of the individuals (Bertram, Laine, and Virkkala, 2000; Memiş, 2018) demonstrate that this contribution reaches the maximum level, especially in those languages where the suffix-root relationship is evident.

Morphological knowledge of a language is the knowledge of that language's operation system. Understanding how the elements work as a system, regardless of their type and content, and knowing the tasks and functions of the parts that constitute this system help to understand and use the target system more effectively. Knowing the operational features of the language that works as a system enables its better use both as a mother tongue and a foreign language. Turkish is an agglutinative language whose operating system is based on the suffixes and in which the suffixes are arranged at the 
end of the words. Two of the most important features of Turkish's being an agglutinative language can be listed as giving new meanings to the words in Turkish with the use of derivational suffixes and making these words operative in sentences through inflectional suffixes. These suffixes have a decisive role in the meaning of the Turkish words when the derivational suffixes which are directly influential in the meaning of the word are considered together and the inflectional words which have an effect on the syntactic meaning of the words. The integrated relationship of meaning and comprehension directly affects the mental interpretation process of the words, in other words, the comprehension skills and development of individuals. For this reason, it is absolutely necessary to take into consideration the decisive impact of the suffixes, especially derivational ones, on the meaning of the words in the development process of the linguistic skills. In Turkish, the derivational suffixes carry out a function in expanding the conceptual field of the language and they play a role in the comprehension process. For this reason, it is very important to develop a receptive vocabulary based on the skills of the students in word formation in the development process of reading comprehension skills. It is anticipated that the use of derivational suffixes will influence the development of reading comprehension skills in terms of giving meanings to the unknown words especially in the reading process (Onan, 2014, p. 360). Therefore, especially the Turkish lessons at middle schools should focus on the activities demonstrating the functions of derivational and inflectional suffixes, and the students should have clear information about these structures with a high level of awareness and on a solid basis (Onan, 2009, p. 261).

Morphological awareness is not only a type of awareness associated with reading comprehension, but it also contributes to other linguistic skills and demonstrates its true impact and benefits on the vocabulary. There are many studies showing that the education given in the teaching process of the native language, second language and foreign language makes great contributions to the development of vocabulary (Bowers, 2012; Good, 2011; Green, 2012; Iyanaga, 2006; Khoury, 2008; Kieffer, 2009; Larsen and Nippold, 2007; Maag, 2007; Memiş, 2018; Miguel, 2013; Mochizuki ve Aizawa, 2000; Zhang, 2009). It is possible to say that agglutinative nature of the Turkish language and its morphology-prone structure can be useful for increasing the morphological awareness, guessing the meanings of the unknown words and giving meanings to the complicated words. This is because the links to the meaning that does not disappear among the derived words in Turkish and the awareness gained in this context help the students to be more successful in their comprehension skills. For this reason, an awareness should be formed in the context of the structural and semantic relationship between the words in the Turkish language during the language education process. The students should be informed and trained on the existence of various strategies that they can use in order to guess the meanings of the unknown words, to improve their reading comprehension skills and to understand the texts more effectively. The students should acquire the morphological analysis skill, which is one of the above-mentioned strategies based on the suffix-root relationship and that can be evaluated within the scope of morphological awareness.

When the Turkish literature is examined, this study is seen to be the first study analyzing the relationship between the reading comprehension and morphological awareness, and this situation indicates a shortcoming in the field. Numerous scientific studies should be performed on the issue of morphological awareness in order to overcome this shortcoming. The researchers should carry out various qualitative and quantitative studies investigating the relationship between the morphological awareness and other linguistic skills and the impact of the morphological awareness training on the basic linguistic skills. Then the obtained results should be compared with the data from similar studies and the outcomes should be presented to the attention of instructors, researchers and relevant authorities. The findings and results to be obtained from these studies should be taken into 
consideration by education planners, and more importance should be given to the morphological awareness training in the language education process.

This study has certain limitations as it is seen in many other studies. Firstly, it is impossible to determine whether the reading comprehension and morphological awareness levels of the middle school students included in this study correctly reflect the levels of all peer students in Turkey. It has been strived to include different regions, cities, schools, and grades in the study as much as possible; however, these variables were naturally confined to the extent of the researcher's capability. A second limitation of the research is that the results of the study could not be compared with the data of any other study and that the outcomes could not be checked since there is no other study on morphological awareness carried out with the participation of Turkish students in the field. It is thought that these limitations will be eliminated in the future by means of the studies to be carried out with different samples.

\section{References}

Anderson, N. (1999). Exploring second language reading: Issues and strategies. Toronto: Ontario: Heinle \& Heinle Publishers.

Anderson, J. C. (2000). Assessing reading. United Kingdom: Cambridge University Press.

Anılan, H. (2004). Bazı değişkenler açısından okuduğunu anlama. Afyon Kocatepe University Sosyal Bilimler Dergisi, 6, 90-102.

Ateş, M. (2008). İlköğretim ikinci kademe ögrencilerinin okuduğunu anlama düzeyleri ile Türkçe dersine karşı tutumları ve akademik başarıları arasındaki ilişki. Unpublished doctoral dissertation, Selçuk University, Konya.

Avcıoğlu, H. (2000). İlköğretim ikinci kademe öğrencilerinin okuma becerilerinin değerlendirilmesi. Eğitim ve Bilim, 25(115), 10-17.

Bacanlı, H. (2000). Gelişim ve öğrenme. (3. bs.). Ankara: Nobel Yayın Dağıtım.

Balc1, A. (2009). İlköğretim 8. sını ögrrencilerinin okuma alışkanlık ve ilgileri üzerine bir araştırma. Unpublished doctoral dissertation, Gazi University, Ankara.

Banguoğlu, T. (1995). Türkçenin grameri. Ankara: Türk Tarih Kurumu Basım Evi.

Baş, T. (2005). Anket (Nasıl hazırlanır, uygulanır, değerlendirilir?). Ankara: Seçkin Yayıncılık.

Bayraktar, İ. (2017). Ortaokul 7. sınıf öğrencilerinin okuma tutumları ile okuduğunu anlama becerileri arasındaki ilişki. International Journal of Languages' Education and Teaching, Volume 5, Issue 4, $582-594$.

Berko, J. (1958). The child's learning of English morphology. Word, (14), 150-177.

Bertram, R., Laine, M. \& Virkkala, M. (2000). The role of derivational morphology in vocabulary acquisition: Get by with a little help from my morpheme friends. Scandinavian Journal of Psychology, 4(41), 287-296.

Bilgegil, K. (2009). Türkçe dilbilgisi. Erzurum: Salkımsöğüt Yayınları.

Block, C. C. \& Pressley, M. (2002). Introduction. C. C. Block, \& M. Pressley, Comprehension instruction: Research-based best practices içinde (s. 1-7). New York: The Guilford Press. 
Bowers, P. N. (2012). Morphological instruction in the elementary classroom. Unpublished doctoral dissertation, Queen's University, Ontario, Canada.

Bozkurt, B. Ü. (2016). Türkiye'de okuma eğitiminin karnesi: PISA ölçeğinden çıkarımlar. Abant İzzet Baysal University Ĕgitim Fakültesi Dergisi, 16 (4), 1673-1686.

Bozpolat, E. (2012). Türkçe Dersinde Birleştirilmişs İsirlikli Okuma ve Kompozisyon Tekniği ile Kullanılan Hikâye Haritası Yönteminin Öğrencilerde Okuduğunu Anlama Becerisini Geliştirmeye Etkisi. Unpublished doctoral dissertation, Firat University, Elazı ğ.

Brassell, D. \& Rasinski, T. (2008). Comprehension that works. Huntington Beach: Shell Education.

Büyüköztürk, Ş. (2017). Sosyal bilimler için veri analizi el kitabı. Ankara: Pegem Akademi.

Can, A. (2017). Spss ile bilimsel araştırma sürecinde nicel veri analizi. Ankara: Pegem Akademi.

Carlisle, J. F. (1995). Morphological aspects of language processing. L. (Ed.), Morphological Awareness and Early Reading Achievement içinde (s. 189-209). Hillsdale, New Jersey: Erlbaum.

Carlisle, J. F. (2000). Awareness of the structure and meaning of morphologically complex words: Impact on reading. Reading and Writing: An Interdisciplinary Journal, (12), 169-190.

Carlisle, J. F. (2003). Morphology matters in learning to read: A commentary. Reading Psychology, (24), 291-332.

Creswell, J. (2012). Educational research: Planning, conducting and evaluating quantitative and qualitative research. Boston: Pearson.

Curinga, R. (2014). The effect of morphological awareness on reading comprehension: A study with adolescent Spanish-English emergent bilinguals. Unpublished doctoral dissertation, The City University of New York, New York.

Çam, B. (2006). İlköğretim öğrencilerinin görsel okuma düzeyleri ile okuduğunu anlama, eleştirel okuma ve Türkçe dersi akademik başarıları arasındaki ilişki. Unpublished master thesis, Osmangazi University, Eskişehir.

Çiftçi, Ö. (2007). İlköğretim 5. sınıf öğrencilerinin Türkçe öğretim programında belirtilen okuduğunu anlamayla ilgili kazanımlara ulaşma düzeyinin belirlenmesi. Unpublished doctoral dissertation, Gazi University, Ankara.

Çiftçi, Ö. \& Temizyürek, F. (2008). İlköğretim 5. sınıf öğrencilerinin okuduğunu anlama becerilerinin ölçülmesi. Mustafa Kemal University Sosyal Bilimler University Dergisi, Cilt: 5 Sayı:9, 109-129.

Deacon, S. H. \& Kirby, J. R. (2004). Morphological awareness: Just 'more phonological'? The roles of morphological and phonological awareness in reading development. Applied Psycholinguistics, (25), 223-238.

Eker, S. (2011). Çă̆daş Türk dili. Ankara: Grafiker Yayınları.

Epçaçan, C. (2009). Okuduğunu anlama stratejilerine genel bir bakış. Uluslararası Sosyal Araştırmalar Dergisi, 2(6), 207-223.

Epçaçan, C. (2010). Çoklu zekâ kuramına dayalı öğretim uygulamalarının ilköğretim öğrencilerinin okuduğunu anlama becerilerine ve duyuşsal özelliklerine etkisi. Unpublished doctoral dissertation, Atatürk University, Erzurum.

Ergin, M. (2008). Türk dil bilgisi. İstanbul: Bayrak Basım/Yayım/Dağıtım.

Erkuş, A. (2005). Bilimsel araştırma sarmalı. Ankara: Seçkin Yayıncılık. 
Fergusson, L. (2006). The effects of explicit teaching of morphemic analysis on vocabulary learning and comprehension and its transfer effects to novel words. Unpublished master thesis, Wichita State University, Wichita.

Foorman B. R., Petscher Y. \& Bishop M. D. (2012). The incremental variance of morphological knowledge to reading comprehension in grades 3-10 beyond prior reading comprehension, spelling, and text reading efficiency. Learn Individ Differ, 22(6): p. 792-798. http://dx.doi.org/10.1016/j.

Fraenkel, J. R., Wallen, N. E. \& Hyun, H. H. (2012). How to Design and Evaluate Research in Education (8th edition). New York: McGraw Hill.

Gelbal, S. (2008). Sekizinci sınıf öğrencilerinin sosyo-ekonomik düzeylerinin Türkçe başarısı üzerinde etkisi. Eğitim ve Bilim, 33(150), 1-13.

Girgin, Y. (2012). İlköğretim 8. sınıf Türkçe ders kitaplarındaki metinlerde kavram haritası kullanımının öğrencilerin okuduğunu anlama becerileri üzerine etkisi. Unpublished doctoral dissertation, Atatürk University, Erzurum.

Göğüş, B. (1978). Orta dereceli okullarımızda Türkçe ve yazın eğitimi. Ankara: Gül Yayınları.

Göktaş, Ö. \& Gürbüztürk, O. (2012). Okuduğunu anlama becerisinin ilköğretim ikinci kademe matematik dersindeki akademik başarıya etkisi. Uluslararası Eğitim Programları ve Öğretim Çalışmaları Dergisi, Cilt: 2, Sayı: 4, 52-66.

Gomez, G. E. (2009). The role of morphological awareness in bilingual children's first and second language vocabulary and reading. Unpublished doctoral dissertation, University of Toronto, Toronto.

Good, J. E. (2011). The effects of morphological awareness training on reading, spelling, and vocabulary skills. Unpublished doctoral dissertation, University of Central Arkansas, Arkansas.

Grabe, W. (1991). Current developments in second language reading research. TESOL Quarterly, 25(3), 375-406.

Grabe, W. \& Stoller, F. L. (2002). Teaching and Researching Reading. Edinburg: Pearson Education.

Green, J. D. (2012). Suffix knowledge within derivational morphological awareness in SpanishEnglish bilingual middle school students. Unpublished doctoral dissertation, University of Connecticut, Connecticut.

Guimaraes S. R. K., Paula F. V., Mota M. M. P. E. \& Barbosa V. R. (2014). Consciência morfológica: que papel exerce no desempenho ortográfico e na compreensão de leitura? Psicol USP, 25(2), 201212. http://dx.doi.org/10.1590/0103-6564A20133713.

Gülensoy, T. (2010). Türkçe el kitabı. Ankara: Akçağ Yayınları.

Gündemir, Y. (2002). İlköğretim sekizinci sınıf ögrencilerinin okuduğunu anlama becerilerinin gelişimlerinin ölçülmesi. Unpublished master thesis. Gazi University, Ankara.

Güneş, F. (2007). Türkçe öğretimi ve zihinsel yapılandırma. Ankara: Nobel Yayın Dağıtım.

Güngör, A. \& Açıkgöz, K. (2005). İşbirlikçi öğrenme ve geleneksel öğretimin okuduğunu anlama üzerinde etkileri ve cinsiyet ile ilişkileri. Kuram ve Uygulamada Eğitim Yönetimi, 43, 354-378.

Harris, T. L. \& Hodges, R. E. (1995). The Literacy Dictionary: The Vocabulary of Reading and Writing. Newark, Delaware: International Reading Association. 
Iyanaga, K. (2006). Determinants of EFL learners' derivational suffix knowledge. Unpublished doctoral dissertation, Temple University.

İşcan, A. (2009). İlköğretim 6. sinıf öğrencilerinin 2005 Türkçe dersi öğretim programındaki anlam bilgisi ile ilgili başarı durumlarının çeşitli değişkenlere göre incelenmesi (Erzurum örneklemi). Unpublished doctoral dissertation, Atatürk University, Erzurum.

Karaağaç, G. (2012). Türkçenin dil bilgisi. Ankara: Akçağ Yayınları.

Karabay, A. \& Kayıran, B. K. (2010). İlköğretim beşinci sınıf öğrencilerinin okuduğunu anlama becerileri ve okumaya ilişkin tutumları arasındaki ilişki. Çukurova University Eğitim Fakültesi Dergisi. 3(38), 110-117.

Karadağ, Ö. \& Kurudayığlu, M. (2010). Türkçedeki kelime türetme özelliğinin ilköğretim öğrencilerinin yazılı anlatımlarına yansıması. Türklük Bilimi Araştırmaları, (27), 437-455.

Karahan, L. (2005). Türkçede söz dizimi. Ankara: Akçağ Yayınları.

Karakuş Tayşi, E. (2007). İlköğretim 5. ve 8. Sinıf öğrencilerinin hikâye ve deneme türü metinlerindeki okuduğunu anlama becerilerinin karşılaştırılması (Kütahya ili örneği). Unpublished master thesis, Gazi University, Ankara.

Karasar, N. (2016). Bilimsel araştırma yöntemi. Kavramlar, ilkeler, teknikler. Ankara: Nobel Yayınc1lik.

Karatay, H. (2010). İlköğretim öğrencilerinin okuduğunu kavrama ile ilgili bilişsel farkındalıkları. Türklük Bilimi Araştırmaları Dergisi, (25), 457-475.

Katz, L. A. (2004). An investigation of the relationship of morphological awareness to reading comprehension in fourth and sixth graders. Unpublished doctoral dissertation, University of Michigan, Michigan.

Kavcar, C. \& Oğuzkan, F. (1987). Türkçe öğretimi. Eskişehir: Anadolu University Yayınları.

Keleş, M. A. (2005). Bolvadin İlçesi Merkez İlköğretim Okullarındaki Sekizinci Sinıf Öğrencilerinin Okuduğunu Anlama Becerileri Üzerine bir Araştırma. Unpublished master thesis, Afyon Kocatepe University, Afyonkarahisar.

Khoury, G. (2008). Vocabulary acquisition in Arabic as a foreign language: The root and pattern strategy. Unpublished doctoral dissertation, Boston University, Boston.

Kieffer, M. J. (2009). The development of morphological awareness and vocabulary knowledge in adolescent language minority learners and their classmates. Unpublished doctoral dissertation, Harvard University.

Kieffer, M. J. \& Lesaux, N. K. (2008). The role of derivational morphology in the reading comprehension of Spanish-speaking English language learners. Reading and Writing: An Interdisciplinary Journal, 21(8), 783-804. doi:10.1007/s11145-007-9092-8.

Korkmaz, Z. (2009). Türkiye Türkçesi grameri şekil bilgisi. Ankara: Türk Dil Kurumu Yayınları.

Kuo, L., \& Anderson, R. C. (2006). Morphological awareness and learning to read: A cross-language perspective. Educational Psychologist, 41(3), 161-180.

Kurnaz, H. (2018). Bilgilendirici metinlerde okuduğunu anlamayı etkileyen faktörler. Unpublished doctoral dissertation, İnönü University, Malatya. 
Kuşdemir, Y. \& Katranc1, M. (2016). Okumada Kaygı ve Anlama: Ana Fikri Bulamıyorum Öğretmenim!. Eğitim ve Bilim, 41(183), 251-266.

Kutlu, Ö., Yıldırım, Ö. Bilican, S. \& Kumandaş, H. (2011). İlköğretim 5. sınıf öğrencilerinin okuduğunu anlamada başarılı olup-olmama durumlarının kestirilmesinde etkili olan değişkenlerin incelenmesi. Ĕgitimde ve Psikolojide Ölçme ve Değerlendirme Dergisi, 2(1), 132-139.

Larsen, J. A. \& Nippold, M. A. (2007). Morphological analysis in school-age children: Dynamic assessment of a word learning strategy. Language, Speech, and Hearing Services in Schools, (38), 201-212. doi: 0161-1461/07/3803-0201.

Leong, C. K. (1991). From phonemic awareness to phonological processing to language access in children developing reading proficiency. D. J. Sawyer, ve B. J. Fox, Phonological awareness in reading: The evolution of current perspectives içinde (s. 217-254). New York: Springer Verlag Inc.

Loudermill, C. S. (2014). An investigation of the relationship between reading comprehension and morphological awareness skills. Unpublished doctoral dissertation, University of Central Arkansas, Arkansas.

Lynn, R. \& Mikk, J. (2009). Sex differences in reading achievement. TRAMES, 13(1), 3-13.

Maag, L. K. (2007). Measuring morphological awareness in adult readers: Implications for vocabulary development. Unpublished doctoral dissertation, University of Florida, Florida.

Mattingly, I. G. (1987). Morphological structure and segmental awareness. Cahiers de Psychologie Cognitive/Current Psychology of Cognition, 7(5), 488-493.

May, F. B. \& Rizzardi, L. (2002). Reading as communication. USA: Prentice Hall.

McCutchen, D., Green, L. \& Abbott, R. D. (2008). Children's morphological knowledge: Links to literacy. Reading Psychology, 29(4), 289-314 doi: 10.1080/02702710801982050.

MEB. (2006). Illköğretim Türkçe dersi (6, 7, 8. sinıflar) öğretim programı. Ankara: Milli Eğitim Bakanlığı Yayınları.

MEB (2015). Türkçe dersi (1-8. sınıflar) Öğretim Programı. Ankara: MEB Yayınları.

MEB (2017). Milli eğitim istatistikleri örgün eğitim 2016/2017 yılı. Ankara: MEB Yayınları.

MEB (2018). Türkçe dersi ögretim programı (İlkokul ve Ortaokul 1, 2, 3, 4, 5, 6, 7 ve 8. sinıflar). Ankara: MEB Yayınları.

Memiş, M. R. (2018). Yapım eki öğretiminin Türkçeyi yabancı dil olarak öğrenenlerin kelime hazinesi, kelime türetme becerisi ve okuduğunu anlama becerisi üzerindeki etkisi. Unpublished doctoral dissertation, Gazi University, Ankara.

Memiş, M. R. \& Kara, M. (2018). Yabancı Dil Olarak Türkçe Öğretiminde Sözcük Yapım Bilgisi Eğitiminin Okuduğunu Anlama Becerisi Üzerindeki Etkisi. International Journal of Language Academy, 6(1), 266-288.

Mertler, C. A. \& Vannatta, R. A. (2005). Advanced and Multivariate Statistical Methods: Practical Application and Interpretation (third edition). United States: Pyrczak Publishing.

Miguel, N. M. (2013). Analyzing instruction and learning of derivational morphology in the Spanish foreign language classroom. Unpublished doctoral dissertation, University of Pittsburg, Pittsburg. 
Mochizuki, M. \& Aizawa, K. (2000). An affix acquisition order for EFL learners: An exploratory study. System, (28), 291-304.

Nagy, W., Berninger, V., Abbott, R., Vaughan, K. \& Vermeulen, K. (2003). Relationship of morphology and other language skills to literacy skills in at-risk second-grade readers and at-risk fourth-grade writers. Journal of Educational Psychology, (95), 730-742.

Nagy, W., Berninger, V. \& Abbott, R. (2006). Contributions of morphology beyond phonology to literacy outcomes of upper elementary and middle school students. Journal of Educational Psychology, (98), 134-147.

Onan, B. (2009). Eklemeli dil yapısının Türkçe öğretiminde oluşturduğu bilişsel (kognitif) zeminler. Mustafa Kemal University Sosyal Bilimler Enstitüsü Dergisi, 6(11), 237-264.

Onan, B. (2014). Anlama sürecinde Türkçenin yapısal işlevleri. Ankara: Nobel Akademik Yayıncılık.

Özder, H., Konedrali, G. \& Doğan, H. (2012). İlkokul beşinci sınıf öğrencilerinin okuduğunu anlama becerilerinin değerlendirilmesi. Uluslararası Ĕ̆itim Programları ve Öğretim Çalışmaları Dergisi, 2(4), 13-26.

Özer Özkan, Y. \& Doğan, B. (2013). İlköğretim 8. sınıf öğrencilerinin okuma becerilerinin kestirilmesinde etkili olan değişkenlerin belirlenmesi. The Journal of Academic Social Science Studies, 6(4), 667-680.

Pacheco, E. C. (2005). Affixes as a strategy for vocabulary acquisition in a first year ESL college reading course. Unpublished doctoral dissertation, University of Puerto Rico.

Pallant, J. (2016). Spss kullanma kılavuzu - Spss ile adım adım veri analizi. (Çev. Balc1, S. ve Ahi, B.) Ankara: Anı Yayınc1lık.

Pardo, L. S. (2004). What every teacher needs to know about comprehension. The Reading Teacher, $58(3), 272-280$.

RSG. (2002). Reading for Understanding: toward R\&D Program in Reading Comprehension. Santa Monica, CA: RAND.

Sallabaş, M. E. (2008). İlköğretim 8. sınıf öğrencilerinin okumaya yönelik tutumları ve okuduğunu anlama becerileri arasındaki ilişki. İnönü University Eğitim Fakültesi Dergisi, 9(16), 141-155.

Sanır, H. (2017). Öğrenme güçlüğ̈̈ olan ve olmayan ortaokul ögrencilerinde okuduğunu anlamayı etkileyen faktörlerin karşılaştırılması: Aracı model testi. Unpublished doctoral dissertation, Gazi University, Ankara.

Saracaloğlu, A. S., Dedebali, N. C. \& Karasakaloğlu, N. (2011). Sekizinci sinıf öğrencilerinin sessiz okuma hızları ve okuduğunu anlama düzeyleri. Ahi Evran University Eğitim Fakültesi Dergisi, 12(3), 177-193.

Sert, A. (2010). İlköğretim altıncı sınıf öğrencilerinin okuduğunu anlama becerilerinin bazı değişkenler açısından incelenmesi. Unpublished master thesis, Selçuk University, Konya.

Sidekli, S. (2005). İlköğretim beşinci sınıf öğrencilerinin öğretici ve öyküleyici metinlere göre okuduğunu anlama becerilerinin sinanmast. Unpublished master thesis. Gazi University, Ankara.

Silva, A. A. M. \& Martins-Reis, V.O. (2017). The influence of morphological awareness on reading and writing: a systematic review. CoDAS, 29(1), 1-8. DOI: 10.1590/2317-1782/20172016032.

Smith, F. (1988). Understanding reading (4th ed.). Hillsdale, NJ: Erlbaum. 
Smith, M. L. (1998). Sense and sensitivity: An investigation into fifth grade children's knowledge of English derivational morphology and its relationship to vocabulary and reading ability. Unpublished doctoral dissertation, Harvard: Harvard University.

Snow, C. E. (2002). Reading for Understanding: Toward a Research and Development Program in Reading. Santa Monica, CA: RAND Corporation.

Temizyürek, F. (2008). Farklı Türlerdeki Metinlerin İlköğretim 8. Sınıflarda Okuduğunu Anlamaya Etkisi. Eurasian Journal of Educational Research, 30, 141-152.

Tighe, E. L. (2015). Assessing the importance of metalinguistic skills to the word reading and reading comprehension abilities of adult basic education students. Unpublished doctoral dissertation, Florida State University College of Arts and Sciences, Florida.

Tompkins, G. E. (2006). Literacy for the 21st century a balanced approach (4. bs.). New Jersey: Pearson Education.

Ürün Karahan, B. (2015). 5. ve 6. sinıf ögrencilerinin okumaya karşı tutum ve motivasyonlarının okuduğunu anlama becerileri ile ilişkisi. Unpublished doctoral dissertation, Atatürk University, Erzurum.

Weiss, E. M., Kemmler, G., Deisenhammer, E. A., Fleischhacker, W. W. \& Delazer, M. (2003). Sex differences in cognitive functions. Personality and Individual Differences, 35(4), 863-875. doi:10.1016/S0191-8869(02)00288-X.

Yazıcıoğlu, Y. \& Erdoğan, S. (2017). Spss uygulamalı bilimsel araştırma yöntemleri. Ankara: Detay Yayıncilik.

Yıldırım, K., Yıldız, M., Ateş, S. \& Rasinski, T. (2010). İlköğretim beşinci sınıf Türk öğrencilerin metin türlerine göre okuduğunu ve dinlediğini anlama düzeyleri. İlköğretim Online, 9, 44-51.

Yıldız, M. (2010). İlköğretim 5. sinıf öğrencilerinin okuduğunu anlama, okuma motivasyonu ve okuma alışkanlıkları arasındaki ilişki. Unpublished doctoral dissertation, Gazi University, Ankara.

Yiğit, F. (2013). 6. sınıf öğrencilerinin anlam bilgisindeki başarı durumlarını etkileyen değişkenlerin incelenmesi: Rize örneği. Ĕ̆itim ve Öğretim Araştırmaları Dergisi, 2(1), 165-175.

Zhang, B. (2009). Incorporating English morphological knowledge into ESL vocabulary teaching. Unpublished doctoral dissertation, Idaho State University, Idaho.

\section{Ortaokul öğrencilerinin okuduğunu anlama ve morfolojik farkındalık düzeyleri ile bu kavramlar arasındaki ilişki üzerine bir araştırma}

\section{$\ddot{O} \mathbf{z}$}

$\mathrm{Bu}$ araştırmanın amacı, ortaokul öğrencilerinin okuduğunu anlama düzeyleri ile morfolojik farkındalık durumlarını belirlemek ve bu iki kavram arasındaki ilişkinin varlığını ortaya koyarak boyutlarını incelemektir. İlişkisel tarama modeliyle gerçekleştirilen araştırmanın çalışma grubu, Türkiye'nin altı farklı bölgesinde bulunan illerde 5, 6, 7 ve 8. sınıf seviyesinde öğrenim gören 1561 öğrenciden oluşmaktadır. 2016-2018 yılları arasında elde edilen verilerin toplanmasında her düzey için ayrı ayrı geliştirilmiş okuduğunu anlama testleri ile morfolojik farkındalık testi kullanılmıştır. Veri toplama araçlarından elde edilen puanların normal dağılım göstermediği 
belirlendiğinden verilerin analizinde parametrik olmayan Mann-Whitney U, Kruskal Wallis ve Spearman Rho testleri tercih edilmiştir. Ulaşılan sonuçlara göre; ortaokul öğrencilerinin okuduğunu anlama seviyelerinin orta düzeyde olduğu, sınıflar arasında okuduğunu anlama bakımından üst sınıflar lehine anlamlı bir başarı farkı bulunduğu ve kızların erkek öğrencilere göre okuduklarını daha iyi anladıkları belirlenmiştir. Elde edilen diğer sonuçlara göre; morfolojik farkındalık düzeyi bakımından 5 ve 6. sınıftaki öğrencilerin düşük, 7 ve 8 . sınıftaki öğrencilerin orta seviyede oldukları, sınıf düzeyleri arasında ve cinsiyete göre anlamlı bir başarı farkının bulunduğu tespit edilmiştir. Son olarak okuduğunu anlama ve morfolojik farkındalık arasında yüksek düzeyde bir ilişki olduğu anlaşılmıştır. Buna göre; okuduğunu anlama başarısı yüksek düzeyde olan öğrencilerin morfolojik farkındalık başarısının da yüksek olduğu, morfolojik farkındalığı düşük olan öğrencilerin ise okuduğunu anlama bakımından da düşük puanlar aldıkları görülmüştür.

Anahtar sözcükler: Okuduğunu anlama, morfolojik farkındalık, ana dili eğitimi, ortaokul düzeyi.

\section{AUTHOR BIODATA}

Dr. Muhammet Raşit MEMiş works as an assistant professor in the department of Turkish language education at Ondokuz Mayıs University. He completed his MA at Ondokuz Mayıs University and PhD at Gazi University in the field of teaching Turkish as a foreign language. His research interests focus on foreign language teaching, second language acquisition and native language education. 